NBER WORKING PAPER SERIES

\title{
MEASURING TOP INCOMES USING TAX RECORD DATA: A CAUTIONARY TALE FROM AUSTRALIA
}

\author{
Richard V. Burkhauser \\ Markus H. Hahn \\ Roger Wilkins \\ Working Paper 19121 \\ http://www.nber.org/papers/w19121 \\ NATIONAL BUREAU OF ECONOMIC RESEARCH \\ 1050 Massachusetts Avenue \\ Cambridge, MA 02138 \\ June 2013
}

We thank Andrew Leigh for providing the computer code used to produce the Atkinson and Leigh $(2005,2007)$ top income shares. We thank Daniel Feenberg, Andrew Leigh, Stephen Jenkins, and Dean Lillard for reading earlier drafts of this paper. This paper uses the confidentialised unit record file from the Household, Income and Labour Dynamics in Australia (HILDA) Survey. The HILDA Project was initiated and is funded by the Commonwealth Department of Families, Housing, Community Services and Indigenous Affairs and is managed by the Melbourne Institute of Applied Economic and Social Research. The authors have no material financial interests that relate to the findings described in this paper and received no outside financial support for the research. Burkhauser over the past 12 months has received funding in excess of $\$ 5,000$ from the National Institute on Disability and Rehabilitation Research and the American Enterprise Institute. In addition he received funding not in excess of \$5,000 from: The Brookings Institution, Employment Policies Institute, Pew Charitable Trusts, and the Smith Group. Hahn and Wilkins over the past 12 months have received funding in excess of $\$ 5,000$ from the Australian Government Department of Families, Housing, Community Services and Indigenous Affairs. The views expressed herein are those of the authors and do not necessarily reflect the views of the National Bureau of Economic Research.

NBER working papers are circulated for discussion and comment purposes. They have not been peerreviewed or been subject to the review by the NBER Board of Directors that accompanies official NBER publications.

(C) 2013 by Richard V. Burkhauser, Markus H. Hahn, and Roger Wilkins. All rights reserved. Short sections of text, not to exceed two paragraphs, may be quoted without explicit permission provided that full credit, including $(\mathrm{C}$ notice, is given to the source. 
Measuring Top Incomes Using Tax Record Data: A Cautionary Tale from Australia

Richard V. Burkhauser, Markus H. Hahn, and Roger Wilkins

NBER Working Paper No. 19121

June 2013

JEL No. H0,I0,J0

\title{
ABSTRACT
}

Atkinson, Piketty, and Saez (2011) survey an important new literature using income tax-based data to measure the share of income held by top income groups. But changes in tax legislation that expand the tax base to include income sources (e.g. capital gains, dividends, etc.) disproportionately held by these groups will conflate such an expansion with an increase in the share of income they hold. We provide a cautionary tale from Australia of how comprehensive tax reform legislation in 1985 substantially altered Australian top income series, especially those that do not separate taxable realized capital gains from other taxable income.

\author{
Richard V. Burkhauser \\ Cornell University \\ Department of Policy Analysis \& Management \\ 259 MVR Hall \\ Ithaca, NY 14853-4401 \\ and University of Melbourne \\ and also NBER \\ rvb1@cornell.edu \\ Markus H. Hahn \\ Melbourne Institute of Applied Economic \\ and Social Research \\ University of Melbourne \\ Faculty of Business and Economics Building \\ 5 th floor \\ Victoria 3010, Australia \\ mhahn@unimelb.edu.au
}

Roger Wilkins

Melbourne Institute of Applied Economic and Social Research

University of Melbourne

Faculty of Business and Economics Building 5 th floor

Victoria 3010, Australia

r.wilkins@unimelb.edu.au 


\section{Introduction}

A major new literature using personal income tax data now measures the share of income captured by the top part of the income distribution. Atkinson, Piketty, and Saez (2011) survey the methodology, main findings, and perspectives emerging from the collective research projects at its core. ${ }^{2}$ What makes this project especially valuable to researchers interested in trends in the level and distribution of income of a country or in making cross-national comparisons of such outcomes is that data from all 22 country studies are updated each year and put on a Paris School of Economics website: http://g-mond.parisschoolofeconomics.eu/topincomes/.

These studies are valuable in tracing the share of taxable income going to the top end of the income distribution beginning early in the $20^{\text {th }}$ century. And they are likely to be a major component of studies of the Global Financial Crisis and its aftermath as data from these years become publically available. However, despite their great potential, especially in capturing long trends in top income growth beginning well before household survey unit-record data existed, these data have limitations. Atkinson, Piketty, and Saez (2011, p. 5) warn that "even within a country, there are breaks in comparability that arise because of changes in tax legislation... and perhaps most important, our series might be biased because of tax avoidance and tax evasion.”

That is, because these top income studies only capture income in the personal income tax base (i.e. taxable income), changes in tax legislation that increase this base may lead them to conflate an increase in the sources of income captured in the tax base with an increase in all income. ${ }^{3}$ When these sources are disproportionately held by top income groups-e.g. dividends,

\footnotetext{
2 These core studies are available in Atkinson and Piketty (2007, 2010) and previously surveyed by Leigh (2009).

${ }^{3}$ A point of confusion for those unfamiliar with the top incomes literature is what is operationally meant by income. It is what we are describing here as taxable income-the amount of total income that is captured in the tax base. This is further confused by the way that different countries' tax offices describe income. This is especially a
} 
capital gains, etc. - tax-based studies may overstate the rise in the actual share of all income held by top income groups. Here we provide a cautionary tale from Australia of how comprehensive tax reform legislation, first announced on September 19, 1985 (Keating 1985) and implemented over the next two years, substantially altered Australian top income series values and their comparability with earlier years, especially in series like Atkinson and Leigh (2007) that do not separate taxable realized capital gains from other taxable income. ${ }^{4}$

Atkinson, Piketty, and Saez (2011) include Australia in their review. Atkinson and Leigh (2007) developed this data series based on ATO tax record tables and Australian Bureau of Statistics (ABS) National Accounts and population data from 1921 to 2003 to trace levels and trends in the share of income held by top income groups. ${ }^{5}$ Leigh updates this series each year and posts it on the Paris website. This series now includes information through 2010.

According to Atkinson, Piketty, and Saez (2011) the main empirical findings from this literature are: most countries experienced a sharp drop in top income shares in the first half of the $20^{\text {th }}$ century; in the second half of the $20^{\text {th }}$ century, top percentile shares experienced a U-shape pattern, with further declines during the immediate post-war decades followed by increases in more recent decades. Most importantly for this paper, the increase was greatest in the Englishspeaking countries of Europe, North America, New Zealand, and Australia.

complication in Australia where the Australian Tax Office (ATO) uses the term "total assessable income" to describe what we are calling taxable income or the income tax base. The ATO uses the term "taxable income" to mean "total assessable income less any deductions allowed under the Income Tax Assessment Act 1936 (or 1997$)$." When we use their terms in the body of the text we refer to them as: "ATO taxable income" and "ATO total assessable income.” In the Appendix we describe in more detail, using ATO language, how we capture the tax base used in the numerator of our top income measures.

${ }^{4}$ The Australian tax year begins in July and ends in June. In this paper we follow the Atkinson and Leigh (2007) convention and denote each tax year by the first of the two calendar years it spans.

${ }^{5}$ National Accounts are used beginning in 1959. For prior years Atkinson and Leigh splice together their “control totals” from various other sources. 
We replicate the top income series in Atkinson and Leigh (2007) and Leigh's updates of it. We add to their work by disentangling taxable realized capital gains from all other taxable income. ${ }^{6}$ We show, as in the U.S., that the rise in the share of income held by Australian top income groups is greater when we include taxable realized capital gains. However we find that much of the major short-term spike in top incomes for tax years 1987 and 1988 is the result of a fundamental change in the treatment of company profits and dividends that more fully captures them in the personal income tax base. More importantly, we find that much of the long-term growth in the Atkinson and Leigh series after 1989 is not the result of an increase in the value of yearly accrued capital gains, or even realized capital gains, but rather an increase in the share of realized capital gains captured in the tax base each year. That is, we show that the decision to, for the first time in Australia, tax longer term realized capital gains (capital gains on property held for more than one year)—but only on property purchased after September 19, 1985—set off a gradual increase in the share of the capital stock subject to capital gains taxed at sale.

Hence our series excluding taxable realized capital gains is a more consistent way of measuring levels and trends in top income groups in Australia over the period of our analysis, 1970 to 2010. Using our adjusted series excluding taxable realized capital gains and correcting for the way profits are treated in the tax base, we find that not only does the share of income of the top 1 per cent not increase as fast or fluctuate as much over time, but the timing of the increase is substantially changed, with most of it occurring between 1985 and $2000 .^{7}$ When we

\footnotetext{
${ }^{6}$ Most of the 22 countries reviewed by Atkinson, Piketty, and Saez (2011) do not include taxable realized capital gains in their top income estimates. Some provide estimates including and excluding it. Only the U.K., New Zealand, Germany, Norway, and Australia provide a single measure that mixes it with other taxable income. The Piketty and Saez (2003) U.S. study focuses primarily on taxable income excluding taxable realized capital gains.

${ }^{7}$ While we will primarily focus on differences between our results and those found by Atkinson and Leigh (2007) for the top 1 per cent, we will later do so for other top income groups up to the top 0.1 per cent.
} 
disaggregate our 1 per cent top income group into subgroups, only the top 0.1 per cent and the top 0.1 to 0.5 percentile groups have substantially increased their income share since 1970 .

Finally, we use the Household, Income and Labour Dynamics in Australia (HILDA) Survey to make a more general point. Measures of the level and trend in income held by top income groups based on tax record data are affected by a country’s personal income tax base. Horizontal equity suggests that a tax base capture income from all sources. But no income tax system does so. With respect to capital gains, it suggests taxing capital gains accrued from all assets each year. However when capital gains are taxed, the tax is usually on realized capital gains, and not all sources of realized capital gains are taxed (e.g. owner-occupied homes).

We estimate the size and distribution (across income groups) of taxable realized capital gains assuming that all capital gains in Australia in 2006 were on assets purchased after September 19, 1985. We compare these results with those using accrued capital gains on these types of taxable assets as our measure and then do so, but only on accrued capital gains on assets that are not taxable (e.g. owner-occupied homes and superannuation funds) as our measure. We find substantially different distributions across these three measures of capital gains. We also find this pattern for 2009. Most importantly, we find substantial differences across our measures in how capital gains changed between 2006 and 2009 for top income groups. Given these results, it is far from clear that including taxable realized capital gains as the measure of capital gains in the top income tax-based literature-just because it is there-is appropriate.

\section{A Summary of the September 19, 1985 Proposals for Tax Reform}

As summarized by Reinhardt and Steel (2006), a growing concern about the equity of the Australian tax system led to the establishment of the Taxation Review Committee chaired by 
K. W. Asprey in the early 1970s. ${ }^{8}$ A major recommendation of the Asprey Report (Asprey et al. 1975), subsequently taken up in an Australia Government draft white paper (Australian Government 1985), was to broaden the tax base to improve equity and efficiency. Labor M.P. and Government Treasurer Paul Keating introduced a proposal for fundamental tax reform based on this white paper on September 19, 1985. His opening statement provides a sense of its magnitude: “Today we are addressing a crisis in our national taxation system that has been left by a succession of Governments to compound year upon year. There was a time when Australia had a reasonably sane and credible taxation system. But that time is long gone. The system has been broken and beaten by an avalanche of avoidance, evasion, and minimisation..... It is the deterioration and decay that occurred in the late 1970s and early 1980s that has now made substantial reform so essential.” (Keating, 1985, p. 2)

We focus on the two reforms that most increased the income base on which personal income taxes were collected and hence the part of income captured by tax record data: changes to the taxation of dividends and changes to the taxation of capital gains. ${ }^{9}$

Dividends. Between 1940 and 1985 Australia maintained a classical company tax system with profits taxed at the company rate and then again at the personal income tax rate when distributed. ${ }^{10}$ The aspects of the Keating proposal on the treatment of company profits and

\footnotetext{
${ }^{8}$ Our summary of the September 19, 1985 tax reform proposal and of the history of relevant Australian tax laws in this section is based on: Keating (1985), Australian Government (1985), and Reinhardt and Steel (2006).

${ }^{9}$ Other significant changes made around this time included non-deductibility of entertainment expenses from 19 September 1985, and taxation of "fringe benefits" (in-kind employee remuneration) from 1 July 1986. Both are likely to have decreased wage and salary income received as in-kind benefits in lieu of cash, and thus led to increased cash wage and salary incomes. The extension of company tax arrangements to public unit trusts which operate a trade or business from 1 July 1988 may also have increased the personal income tax base.

${ }^{10}$ Australia first taxed company profits in 1922. But at the same time a non-refundable rebate system was retained and applied to all dividends, making this effectively a withholding tax for individuals whose marginal tax rate was greater than the company rate. In 1940 this rebate was "temporarily" removed. (See Reinhardt and Steel 2006 for additional details.)
} 
dividends were given Royal assent in June 1987. As a result the company marginal tax rate increased from 46 to 49 per cent for income tax year 1987. This rate equalled the highest marginal tax rate on personal income. But under the new 100 per cent imputation tax system in the reform legislation, these company taxes effectively became withholding taxes since their payment could be used to offset personal income tax on dividends or any other taxes. ${ }^{11}$ Hence this was a major reduction in the effective tax rate on dividends, with the greatest reduction in tax rates going to those with the lowest marginal personal income tax rate. ${ }^{12}$

Holding aside whether this is good or bad tax policy, for purposes of measuring top incomes, this change in tax law had a major and "artificial” impact on top income trends. Unless accounted for in the data series, it will results in an overstatement in the growth of top income shares. This is the case because it mixes increases in measured income, because more of it is now taxable, with real increases in the dividends (market income) paid out of company profits. Because this previously uncounted income predominately went to higher income groups, it artificially increases their share of income relative to the way it was counted prior to 1987.

For example, assume a 49 per cent marginal company tax and a 49 per cent highest marginal personal income tax prior to the change in tax law. In this case, $\$ 100$ in profits results

\footnotetext{
${ }^{11}$ It became fully refundable in 2000. Handley and Maheswaran (2008) estimate that, between 1990 and 2000, resident individuals and funds were able to utilize 67 per cent of their tax credits to reduce their tax liabilities. The change in the tax law to make it a fully refundable tax credit increased this utilization rate to 81 per cent between 2001 and 2004.

${ }^{12}$ One reason for the passage of this legislation was to treat profits by companies in the same way profits by trusts were treated. Australian Government (1985) identified the shifting from companies and partnerships to public and private trusts as a major threat to the tax system since it was increasingly becoming a relatively low cost legal vehicle for doing business in the 1970s and 1980s that successfully circumvented the classical taxation system. They found, based on tax record data, that trusts grew from 117,616 (aggregate net income of \$0.312 Billion) in 1972 to 258,846 (aggregate net income of $\$ 2.682$ Billion) in 1982. They concluded that: "The phenomenal growth in recent years in private business and trading trusts has reflected a desire to avoid the two-tier taxation of company income which can feature under the private company structure.” (p. 55) Changes to tax rules reduced this behaviour beginning in 1981. Comprehensive tax reforms effectively ended the classical system of company taxation in Australia in 1986.
} 
in \$51 in after-tax company profits, which we assume are fully distributed to a person in the 49 per cent top marginal tax bracket. This $\$ 51$ is counted as personal income in that person's tax base. And that person pays a 49 per cent tax on that income resulting in net income of \$26 and an effective marginal tax rate of 74 per cent.

After the law, the company still pays the $\$ 49$ company tax, but now it effectively is in the form of a withholding tax on profits assigned to that taxpayer. The company still pays out the \$51 dividend, but now the tax system counts the full $\$ 100$ of profit associated with that dividend against that person’s taxable personal income—an increase of $\$ 49$. And the person must pay $\$ 49$ on that $\$ 100$, but the person has already paid it via the withholding tax that the company paid up front. Hence, the net result of this change in the way taxes are collected is a reduction in the highest effective marginal tax on dividends from 74 per cent to 49 per cent. However, since the economic idea behind the top income literature is pre-tax personal income, this after-tax income number is not relevant. It is the pre-tax number that is relevant, and that has increased from $\$ 51$ to $\$ 100$ as captured in the personal income tax base. ${ }^{13}$

Conveniently, this difference of $\$ 49$ is exactly the value of the personal income tax credit which is identifiable in the more detailed Australian tax tables we consistently use in this paper. Because we base our top income series on these more detailed tax tables we are able to subtract this credit from taxable income. By doing so, we are able to generate pre-tax income values that are consistent before and after this change in tax rules. Atkinson and Leigh (2007) do not account for this aspect of the change in the tax reforms in their analysis. Rather, it is simply included as additional income in the more aggregated tax tables they use. By explicitly

\footnotetext{
${ }^{13}$ The increase in the tax base is even larger to the degree that what would have been retained earnings prior to 1986 that were realized by stockholders via non-taxable long term capital gains are now realized as profits and paid out as dividends.
} 
considering this change in the tax rules on the taxable income base, we will be able to distinguish the change in the income tax base from the increase in dividends which is both the effect of changes in market forces and the effect of companies increasing the share of profits they pay out in dividends because of the fall in the effective marginal tax rate on dividends.

An important feature of this specific aspect of the tax reforms proposed in 1985 is the way it was implemented. While the government's decision to move from a classical to a 100 per cent imputation tax system was announced on September 19, 1985, this law was not officially adopted until June 1987 and its effective reduction in the marginal tax on dividends only began for dividends received on or after July 1, 1987, the start of the 1987 tax year. As we will see, this delay between its announcement and its start had a major short-run effect on top income measures in tax year 1987 and 1988 that is consistent with behavioural changes in the timing of dividend payments related to the roll-out of these tax reforms.

Capital Gains. Prior to 1985, Australia had no general tax on capital gains. Hence, almost no capital gains were captured in tax record data, since most capital gains were excluded from the personal income tax base. In 1972 realized capital gains on most assets were included in the tax base under Section 26AAA of the tax law, but only for short-term capital gains (those on assets held less than one year), and excluding owner-occupied housing. A tax on realized capital gains on assets based on speculation existed as far back as the 1920s. But it was not systematically enforced and it generated little revenue. ${ }^{14}$

\footnotetext{
14 "Section 25 taxes, inter alia, profits from the sale of property acquired for the purpose of profit-making by sale. This section raises the question of what was the dominant purpose of the taxpayer at the time of acquiring the property. Because of the subjective nature of this test, the section (and its predecessor section 26(a)) has been criticised as having uncertain application. This section also does not raise a large amount of revenueapproximately \$30 million was raised in 1982-1993 from individuals under section 26(a) or Section 26AAA)" (Australian Government (1985, p. 77). For a fuller discussion see Chapter 7 of Australian Government (1985).
} 
This aspect of the Keating proposal on the treatment of capital gains was given Royal assent in June 1986. It substantially expanded the income base on which taxes were collected by including most realized capital gains regardless of how long the asset was held. But to soften its effect, the reform applied only to assets purchased after September 19, 1985. Certain types of assets continued to be exempt, most importantly owner-occupied housing. ${ }^{15}$

This change in tax law had a substantial effect on the income that is captured in the personal income tax base. As was the case with dividends discussed above, unless accounted for, the pre-tax taxable income measure used in the top income literature will once again conflate an increase in the share of income that is taxable with an actual increase in income-in this case, via an increase in the share of the asset base on which realized capital gains are taxed.

Unlike the effect of the change in the tax law on dividends, this artificial increase in income is not primarily a short-run phenomenon. Rather it grows over time with the stock of assets purchased after September 19, 1985 and the share of realized capital gains that enter the tax base. Atkinson and Leigh (2007) do not mention this consequence of the 1985 change in the tax law and do not control for this artificial increase in their income base. We will do this by disentangling taxable realized capital gains income from all other taxable income and provide a more consistently measured top income series from tax records that does not include this conflated capital gains income measure.

\footnotetext{
${ }^{15}$ Between 1985 and 1999, an indexation system was applied so that taxes were only paid on inflation-adjusted capital gains. In 1999, the indexation system was replaced with a discount of 50 per cent on capital gains realized on assets acquired after September 19, 1999. Holders of assets acquired before 1999 were given (and still have) the option of using either the indexation method, but only for adjustments for inflation up to 1999, or the 50 per cent discount method. Throughout the operation of the capital gains tax, net capital losses have been able to be carried forward to offset capital gains in subsequent years.
} 


\section{Data and Methods}

Empirical researchers are limited in their measure of income to the types of income collected in their database. Estimates of income and its distribution based on unit-record survey data like the Household, Income and Labour Dynamics in Australia (HILDA) Survey and the Australian Bureau of Statistics (ABS) Survey of Income and Housing that do not contain income from capital gains, focus on household size-adjusted, post-tax, post-government transfer, in-cash income of individuals. They do not attempt to estimate capital gains from another source. In doing so they are consistent with most OECD studies based on country-level, household-unitrecord-level data surveys. See Brandolini and Smeeding (2009) for a review of this literature.

CBO (2011, 2012) and Armour, Burkhauser, and Larrimore (2013) are recent exceptions in the United States literature based on unit-record survey data that use household income as the sharing unit. They impute the value of capital gains from Internal Revenue Service (IRS) tax records along with other income sources not found in the U. S. Current Population Survey to more fully measure household income. CBO $(2011,2012)$ use taxable realized capital gains as their measure of capital gains. Armour, Burkhauser, and Larrimore (2013) use both a taxable realized capital gains measure and one more consistent with Haig-Simon principles-the yearly accrued value of capital gains. Using their measure of taxable realized capital gains, Armour, Burkhauser, and Larrimore (2013) are able to replicate the very large increases in income over the 1989 to 2007 period among top income groups found by CBO (2012). But using their yearly accrued value measure of capital gains they find that these top income groups had smaller gains than did lower income groups. Hence they conclude that the choice of measure of capital gains used in income studies can substantially alter the trends in income observed. 
A newer inequality literature estimates the income controlled by top income groups based on personal income tax records. It focuses on the pre-tax income of tax units. Atkinson and Leigh (2007) were the first to estimate the share of income going to top income groups in Australia using tax record data. This seminal study measures levels and trends in top incomes from 1921 to 2003 based on ATO data in the Australian Taxation Statistics component of the Annual Reports of the Commissioner of Taxation combined with ABS National Accounts data (as well as a splice of data from other sources prior to 1959 as their control of total income) and ABS population data. Their unit of analysis is the tax unit, which in Australia is the individual. They assume that all persons aged 15 and over are potential tax units, and indeed estimates of top income shares relate only to persons aged 15 years and over. For example, the interpretation of the estimated income share of the top 1 per cent is "the proportion of total income going to the top 1 per cent of individuals aged 15 years and over.”16

The key elements of Atkinson and Leigh's method (described in more detail in the Appendix) are as follows. The number of individuals in the top $x$ per cent is derived from ABS estimates of the total population aged 15 years and over. The total income of the top $x$ per cent is then obtained from tax tables in the Australian Taxation Statistics. This total pre-tax taxable income value is then divided by aggregate household income, obtained from National Accounts data. For example, on June 30, 2011, the ABS determined that 18.111 million Australians were aged 15 and over, implying 181,110 were in the top 1 per cent income group. The total income of the top 181,110 people in the tax data in $2010-11$ is then calculated ( $\$ 80.2$ billion). This value

\footnotetext{
${ }^{16}$ In principle, a taxpayer can be younger than age 15 (even a newborn baby can be required to file a tax return), but in practice the number of taxpayers under 15 years of age is negligible.
} 
is then divided by total household income in 2010-11 obtained from the National Accounts data (\$881.8 billion) to produce the income share of the top 1 per cent (9.1 per cent). ${ }^{17}$

Here, using Atkinson and Leigh’s methods we replicate their findings for the period from 1970 to 2003 using ATO tax (Australian Taxation Statistics) data and the ABS 2004 National Accounts (Household Income Account) and population data. Leigh has updated the Atkinson and Leigh top income series each year since then, using the next year of these data. We are also able to replicate these yearly values from 2003 to 2010. But we argue that because the National Accounts and population data Leigh uses are preliminary data for the year they are announced, their continued use in subsequent years, without updating them based on subsequent ABS corrections, will introduce unnecessary noise. Furthermore, National Accounts and population data are subject to periodic revisions of concepts, definitions, and methods. Such revisions, when they occur, are typically applied retrospectively, so that using the most recent release for all previous years produces a more consistent total income series. Therefore we use the most updated ABS series in our analyses. Atkinson and Leigh (2007, p. 250, fn. 3) recognize that it would be valuable to produce top income series with and without capital gains, but state that “Because of the manner in which Australians' income tax statistics are tabulated, we have not attempted to estimate top income shares excluding capital gains.” Their reticence to attempt to exclude capital gains is understandable, particularly given their focus on producing a long-run

\footnotetext{
${ }^{17}$ This implicitly assumes that every individual over the age of 15 is a self-contained sharing unit whose income is not shared with other members of his or her household. Those under 15 are implicitly assumed to be dependents of these tax units but not considered to have any effect on economic well-being. As Burkhauser, Larrimore and Simon (2012) point out, these assumptions will result in trends in the income of tax units differing from trends in the sizeadjusted household income of persons. This will overstate the growth in the share held by the top 1 per cent when tax units per household increase or when the number of persons in a household declines.
} 
series. ${ }^{18}$ But by not separating taxable realized capital gains from all other taxable income, the Atkinson and Leigh income tax series conflates an increase in the share of realized capital gains after 1985 that are taxable, and hence in their taxable income base, with an increase in realized capital gains. By doing so, their series systematically overstates the increase in income going to top income groups. ${ }^{19}$

Conveniently, the ATO in their more detailed Australian Taxation Statistics tax tables, which we use in this paper, include tabulations of realized capital gains by ranges of ATO taxable (i.e. total assessable income less deductions) income, with ATO total assessable income also available for the same ATO taxable income ranges. Hence we are able to separate taxable realized capital gains from other taxable income over the entire period. ${ }^{20}$ Doing so, we provide a measure of pre-tax income that is both of value in its own right and a more consistent measure of income derived from tax data. We also use the more detailed tax record data series in the Australian Taxation Statistics since 1979 to adjust our series for the 1987 change in tax laws related to dividends. We do so by subtracting the primary imputation credit going directly to individuals based on the profits associated with their dividends as well as the subsidiary imputation credit provided on the dividends going to trusts and then passed on to individuals.

\footnotetext{
${ }^{18}$ Creating such a series is not without its problems. Australian Taxation Statistics did not provide information on taxable realized capital gains until 1969. Hence it is not possible to extract taxable realized capital gains from other taxable income before then. However, during this earlier period, realized capital gains were only collected on property that the tax office could demonstrate was purchased primarily for "the purpose of profit-making by sale." In addition, Australian Government (1985) suggests they were not a large source of revenue in 1982-1983. Hence while realized capital gains may have been an important part of the income of top income groups, it is likely that taxable realized capital gains did not play an important role in their income prior to 1970. Hence our taxable income without taxable capital gains series beginning in 1970 can plausibly be linked to top income values that contained some unknown amount of taxable realized capital gains in earlier years.

${ }^{19}$ In addition, because the total income value they use in the denominator is derived from National Accounts data that do not include capital gains, including any amount of capital gains to the numerator that is not also added to the denominator is inconsistent.

${ }^{20}$ Full details on how we separate realized capital gains from other taxable income are provided in the Appendix.
} 


\section{Results}

Alternative estimates of the top 1 per cent. Figure 1, based on Appendix Tables A1 through A4, provides alternative estimates of the share of income held by the top 1 per cent of Australians for tax years 1970 to $2010 .^{21}$ In discussing our results we show how important it is to take into consideration the two tax reforms announced in September of 1985 in understanding how much top income shares have increased over this 40 -year period. To emphasize this point we divide the years in Figure 1 into three parts. The first is 1970 to 1985, years before these tax reforms were implemented. The second is 1986 to 1988, years in which these reforms increase the income base and top incomes in the short run. The third is 1989 to 2010, years in which these reforms increase the income base and top incomes in the longer term.

Share line (1) reports top 1 per cent income shares whose exact values are found in Appendix Table A1. It replicates the level and trend found in Atkinson and Leigh (2007) through 2003 as well as the updated values reported each year by Leigh using preliminary ABS National Accounts and population data thereafter. Share line (1) includes taxable realized capital gains in its income base. We replicated these values based on Leigh’s programs.

Share line (2) reports top 1 per cent income shares whose exact values are found in Appendix Table A2. It is based on ABS data that are consistently updated to 2010. Atkinson and Leigh (2007) top income values reported in share line (1) are based on ABS data for the years 1970 to 2003 that include ABS revisions for all prior years up to 2003. Thereafter, Leigh reports each additional year of data updated by ABS for that year, but does not adjust previous years based on these new updates. Share line (2) uses the latest ABS standards as of 2013 for all years.

\footnotetext{
${ }^{21}$ Appendix Tables A1 through A4 also contain values for other top income groups from the top 10 per cent to the top 0.01 per cent.
} 
The first two share lines are somewhat different over much of the 1970 to 2003 period.

However, these differences are ones of level, not direction. They primarily reflect a major revision to National Account concepts and definitions made by the ABS in 2004 that the ABSand we, using their revisions—-have retrospectively applied to the data for all preceding years. In contrast, Leigh, in adding years, has included this major revision for 2004, but not for earlier years. As a result, share line (1) shows a decline of 0.29 percentage points in the share of income of the top 1 per cent from 2003 to 2004 instead of the increase of 0.41 percentage points we find using our single consistent ABS series in share line (2). Thereafter, the minor differences in these two series are primarily due to our using the 2012 corrections consistently for all years while Leigh continues to simply add the current year's base ABS numbers. ${ }^{22}$

Share line (2) makes a better case for the view that the share of income controlled by the top 1 per cent consistently increased from 2001 to 2006. It also suggests that the share of income held by the top 1 per cent in Australia is sensitive to international business cycles_-2001 was a recession year in the United States and most other major western industrial countries and was followed by five years of economic growth until the start of the Global Financial Crisis in $2007 .{ }^{23}$ In all subsequent analyses we will contrast share line (2) with our other series—-that also

\footnotetext{
${ }^{22}$ As discussed in more detail in the Appendix there are also slight differences between these two lines because we consistently use the more detailed tables in the ATO tax series (Commissioner of Taxation, 1973-2013) that allow us to disentangle the various sources of income that are taxed. In contrast, Atkinson and Leigh always use the tax table that has the most income brackets. In many years these are the same tables. As Appendix Table A1.2 shows, our use of the more detailed tax tables only accounts for a very small part of the difference between these two lines.

${ }^{23}$ Updating top income series each time the government updates its National Accounts data has the advantage that the new series uses the best available data and does so in a consistent manner. But it has the drawback of requiring all years of the data to be re-valued. This can be especially troublesome for very long time series that contain splices in the data related to the introduction of the National Accounts data into the denominator. For secondary users of the data any changes in earlier yearly values will make it more difficult to replicate past research using previous versions of the data series. Hence committing to consistent updating of the data rather than merely adding yearly iterations would at a minimum require data repositories like the one at the Paris School of Economics to maintain all past versions of the data and assign version numbers to successive series. If the yearly changes are small, one could argue that this added complexity in documentation is not worth the effort. However in cases where the change in
} 
use the updated ABS data-since we consider series (2) to be the preferable way to update the original Atkinson and Leigh (2007) series, especially for those who are primarily interested in comparing years since 2003 with previous years. To do otherwise is to miss the consequences of changes in National Accounts methods on the inter-temporal comparability of estimates.

Share line (3) reports top 1 per cent income shares whose exact values are found in Appendix Table A3. It reports the share of income held by the top 1 per cent adjusting for the changes with respect to dividends contained in the 1985 tax proposals. As discussed above, while the change in dividends was announced on September 19, 1985, the movement to a 100 per cent imputed tax system and its subsequent effect on marginal tax rates was only for dividends received after July 1, 1987, the start of the 1987 tax year. As can be seen, there is a major spike in the top 1 per cent share of income in both share lines (1) and (2) in 1987 and again in 1988 that we will show is largely related to increases in dividends and in the primary and subsidiary imputation credits associated with the profits linked to them. Share line (3) subtracts these credits from taxable income so that our income measure consistently excludes this component of profits. Doing so substantially reduces the size of the spike. The share of income controlled by the top 1 per cent falls in 1989 in all three series but still remains considerably above 1985 levels in each. In subsequent years, share line (3) continues to show a substantial increase in the share of pre-tax income held by the top 1 per cent, but the level is lower.

Share line (4) reports top 1 per cent income shares whose exact values are found in Appendix Table A4. It removes all taxable realized capital gains from the income included in 
share line (3). These two lines best represent the share of income with and without realized capital gains controlled by the top 1 per cent from 1970 to 2010 based on tax record data. ${ }^{24}$

There is almost no difference between share lines (3) and (4) prior to 1986, since realized capital gains only started to be systematically taxed in 1972, and then only on property held less than one year. The vast majority of capital gains did not enter the tax base. This began to change after the implementation of the 1985 tax reforms in 1986. But over the first few years there is little or no difference between these two series, since most realized capital gains were on assets purchased prior to September 19, 1985, and were therefore not taxable. But over time, the share of assets purchased after September 19, 1985 grew and with it the income base on which realized capital gains are taxed. Therefore, it is not obvious how much of the difference between these two series is due to increases in realized capital gains and how much is due to increases in the share of realized capital gains now taxable and included in the income base.

The level and trend in the share of income not including realized capital gains held by the top 1 per cent (share line 4) are different from those based Atkinson and Leigh (2007) and Leigh's updates, even when we adjusted them for changes in ABS National Accounts methods in share line 2. (See: Appendix Table A5 for exact yearly differences between share lines 2 and 4.) There are virtually no differences in these three share lines prior to the 1985 tax reform's implementation in 1986. But the differences are larger between 1986 and 1989 and, we will

\footnotetext{
${ }^{24}$ In creating our series without capital gains and imputation credits, we subtract these components from the income measures in each income bracket before calculating the top income shares. This implicitly assumes that capital gains and imputation credits within an income bracket are the same proportion of total income for all individuals within the bracket. That is, we assume no re-ranking of individuals after removal of capital gains and imputation credits. We test the sensitivity of this assumption using ATO unit record data from their " 1 per cent individual sample file" which is available for the tax years from 2003 to 2009. Doing so, we show that effects of re-ranking are relatively small and thus our findings are robust. See Appendix Table A10 and the discussion around it in the Appendix. The unit record data is useful for testing the robustness of such assumptions, but it has the disadvantage that, for confidentiality reasons, the top 1 per cent of each source of income is top coded. As a consequence, it is less valuable than the tax tables for measuring top incomes.
} 
argue below, are almost entirely accounted for by the change from a classical to an imputed tax on profits (share line 3). After 1990, the differences are increasingly larger and, we will argue below, are primarily accounted for by the growing importance of taxable realized capital gains income-some due to increases in the growth of realized capital gains and some because of the share of this income captured in the tax base, in the portfolio of the top 1 per cent. ${ }^{25}$

Changes in the portfolio of income of the top 1 per cent. In Figure 2 we provide evidence that the differences in Figure 1 between share line (2) and share lines (3) and (4) are the result of the 1985 tax reforms. Figure 2 uses information in the more detailed tables in the Australian Taxation Statistics series (Commissioner of Taxation, 1973-2013) that allow us to disentangle the various sources of income that are taxed. We do so for share line (2) to show how the types of income held by those in the top 1 per cent group change over the period from 1979 to $2010 .{ }^{26}$

As discussed above, an effective reduction in the tax on dividends was announced on September 19, 1985, but only for dividends received after July 1, 1987, the first day of the 1987 tax year. Note that the share of dividends in the income portfolio of the top 1 per cent over the seven years from 1979 through 1986 rises slightly from 2.2 to 3.1 per cent. This increases to 6.0 per cent in 1987 and 11.8 per cent in 1988, the first two tax years in which the decline in the marginal tax rates on dividends is in place.

\footnotetext{
${ }^{25}$ In the Appendix (Appendix Figures A2.1 to A2.4) we repeat our analysis as shown in Figure 1 for subcomponents of the top 1 per cent income group. We find the same differences between each of our share lines as discussed here. These values can be derived from values reported in Tables A1-A4.

${ }^{26}$ Figure A1.1 in the Appendix presents an alternative view of the composition of the incomes of the top 1 per cent, showing the share of ATO total assessable income of each of seven components: primary imputation credits, subsidiary imputation credits, capital gains, dividends, net partnership and trust income, salary and wages, and all other income. Both Figures 2 and A1.1 are limited to the period from 1979 to 2010 because specific information on income components other than salary and wages are only available beginning in 1979. Income on dividends did not begin until tax year 1982. In the prior three years we use the broader dividends and interest category and approximate the importance of dividends in those three years. (See the Appendix for a fuller discussion.) We also created these values for the subcomponents of the top 1 per cent. They are available from the authors.
} 
But in addition to this increase in dividends, the income of the top 1 per cent now includes the primary imputation credits associated with the profits on which these dividends are based. This income share, which was zero prior to 1987, now makes up 4.5 per cent of their portfolio in 1987 and 10.8 per cent in 1988. The dividends paid to partnerships and trusts but distributed as income to individuals now come with a subsidiary imputation credit attached to them. The income the top 1 per cent receives from these credits makes up a total of 1.7 per cent of their portfolio in 1987 and 4.2 per cent in $1988 .{ }^{27}$ This addition of income from profits that was not counted as personal income prior to 1987 explains the difference between share lines (2) and (3) reported in Figure 1, in the size of the short-run spike in top incomes in 1987 and 1988.

This pent-up short-run spike in the pay-out of profits to individuals in the form of dividends in Figure 2 is consistent with firms deferring profits and dividends that would have been paid in tax years 1985 and 1986 after the announcement of the government's tax reform plan but before its effective date. As can also be seen in Figure 2, in 1989 dividends fall but to a level higher than over the 1979 to 1986 period, reflecting the lower marginal tax rate on dividends. The share of income associated with primary and subsidiary imputation credits also falls from its 1988 height, both because dividends fall and because subsequent tax reforms lowered the tax rate on company profits and hence the difference between dividends and the profits associated with them. For purposes of measuring top income shares from tax record data, if the tax on profits were zero and all profits were paid out in dividends, then there would be no difference in Figure 1 share lines (2) and (3).

\footnotetext{
${ }^{27}$ Also included in Figure 2 is the share of net partnership and trust income in the income portfolio of the top 1 per cent. Note that, after declining as a share of income between 1979 and 1982 and then increasing somewhat up to 1986, there is also a spike in this income in 1987 and 1988. This spike reflects the increase in dividends held by partnerships and trusts that are paid out as partnership and trust income to the top 1 per cent, which is the basis for the subsidiary imputation credits these individuals receive.
} 
Table 1 shows the exact shares of dividends and the tax credits associated with them in the portfolio of the top 1 per cent for 1985 to 1989 based on income series (2) - the years just before and just after the short-run spike years. It also shows those values for the subcomponents of this top 1 per cent income group. The share of dividends in the portfolio of the top 0.1 percentile (5.4 per cent) is higher than in the 0.1 to 0.5 percentile (2.8 per cent) and in the 0.5 to 1 percentile (2.0 per cent) in 1985, the year the tax reforms were announced. The growth in the share of dividends over the spike years from 1986 to 1988 for the 0.1 percentile is also greater, as is the difference between 1985 and 1989. But so is the share of tax credits in their portfolio, which artificially increases the pre-tax measure of income used in the top income literature. In spike year 1988, 48.2 per cent of the income of the top 0.1 percentile group was in dividends and the tax credits associated with them-more than 10 times the share of dividends in their portfolio in $1986 .^{28}$ But only 20.2 percentage points of this spike were in dividends; the other 27.9 percentage points were in tax credits.

Figure 2 also traces the share of taxable realized capital gains in the portfolio of the top 1 per cent. As can be seen, taxable realized capital gains (the measure of capital gains in the taxbased top income literature) made up a trivial share of the taxable income of this group between 1983 and 1985 (between 0.2 and 0.4 per cent) since only capital gains on assets held less than one year entered the taxable income base. This changed in 1986, since assets purchased after September 19, 1985 were taxed in 1986 even if held for more than one year-past September 19, 1986. So unlike dividends that did not increase as a share of the income of the top 1 per cent until 1987, and in the case of the top 0.1 per cent actually fell in 1986, the share of capital gains

\footnotetext{
${ }^{28}$ Part of the reason for this huge spike is that dividends fell from 5.4 to 4.5 per cent of their portfolio between 1985 and 1986, the year after the announcement of the decline in marginal tax rates and the year before they were implemented.
} 
in the portfolio of the top 1 per cent as measured in the tax base did increase in 1986. But since these potentially taxable assets—-those held more than one year-only made up a small part of the stock of assets and the share of realized capital gains taxed in 1986, the increase was only to 1.8 per cent. While some of this increase is the result of market forces, it is also because a larger share of their total capital gains were now subject to tax and hence now artificially included in the share series (2) and (3) in Figure 1.

Figure 2 also shows that the increase in the share of realized capital gains in the portfolio of the top 1 per cent only increased gradually over the next few years. Hence, unlike dividends, it played no role in the spike in the share of income controlled by the top 1 per cent in 1987 or 1988 shown in Figure 1. The reason there is no difference between share lines (3) and (4) for those years is that the share of capital gains included in the tax base did not grow much at first. Unlike the effect of tax reform on dividends, which had it biggest distortion effect (difference between share lines (2) and (3)) with respect to a change in the share of the income that entered the tax base in these spike years, the distortion in the share of realized capital gains that are taxed has grown as the share of capital gains on assets purchased after September 19, 1985 has grown.

As Figure 2 shows, taxable realized capital gains grew from less than 1 per cent of the portfolio of the top 1 per cent before 1986 to a high of 15 per cent in 2006, just before the Global Financial Crisis. The difference between share lines (3) and (4) in Figure 1 is explained by the growth in the share of capital gains in the portfolio of the top 1 per cent found in Figure 2. What is unknown is the degree to which this difference is simply the result of the broadening of income counted in the tax base due to the tax reforms of 1985.

Effects of adjustments on alternative top income groups. Figure 3 summarizes the effects of excluding dividend imputation credits and taxable realized capital gains on alternative top 
income groups. (See: Appendix Table A4.1 for the exact values in this figure.) It shows the percentage difference in the income share of each top income group using an income series including dividend imputation credits and capital gains (e.g. share series 2 in Figure 1 for the top 1 per cent ) and one that does not (e.g. share series 4 in Figure 1 for the top 1 per cent). We focus only on 1985 to 2010 since, as discussed above, virtually no difference exists in these series before the 1985 tax reforms. The difference between our adjusted Atkinson and Leigh top income series including taxable realized capital gains and imputation credits and our preferred series without them is greatest for the highest top income group (those in the top 0.1 per cent). In spike year 1988 it is 40.9 per cent—all caused by including dividend imputation credits. It falls to 14.2 per cent in 1989 but builds again as a greater share of capital gains becomes taxable. The peak difference in the two series— 54.5 per cent—occurs in 2006, the tax year before the Global Financial Crisis.

The difference in these two series is greatest for the top 0.1 per cent since they get the most disproportionate amount of imputation credits and realized capital gains entering the tax base after the implementation of the 1985 tax reforms. While the 1988 spike is still observable for the 0.1 to 0.5 and the 0.5 to 1.0 percentile top income groups, it is smaller, as is the spike for the sum of these groups captured in the top 1 per cent. Figure 3 offers a simple measure of the differences in growth in income shares of these various top income groups using the two series between 1985 and any other year. Between 1985 and 2010, the difference is 31.5 per cent for the top 0.1 per cent group and 15.9 per cent for the top 1 per cent group.

Changes in top income shares using our preferred series. In Figure 4 we use our preferred series 4 measure of income excluding taxable realized capital gains and dividend imputed credits to show how levels and trends in the share of various top income groups have changed between 
1970 and 2010. We once again separate these years into: those before tax reform (1970 to 1985), immediately after tax reform (1986 to 1988), and 1989 to 2010. (All values for this figure are from Appendix Table A4.2 which is derived from Appendix Table A4.)

Focusing first on the second vingtile (the top 5 to 10 percentiles), we see a slight decline (2.7 per cent) in their share of income between 1970 and 2010. There is a slight increase between 1970 and 1985, a small spike in 1986 to 1988, but one that is much less pronounced than for the top 1 per cent and a slight overall decline since, but with some growth since 2008.

When we look at those in the bottom part of the top vingtile (the top 1 to 5 percentiles), there is a slight increase (5.2 per cent) in their share of income between 1970 and 2010 . There is a slight decline before 1986, a small spike in 1986 to 1988, a return to slightly below their 1970 level in 1989, and modest growth since. They also display some growth since 2008.

We reproduce the share of income held by the top 1 per cent first reported in Figure 1. Their share of income increased substantially between 1970 and 2010 (39.7 per cent). There was a clear decrease in their income between 1970 and 1985, followed by a substantial spike in 1986 to 1988 . Their income share in 1989 was noticeably higher than in 1985, returning to approximately the share of income they controlled in the early 1970s. It continued to grow until 2000. The recession in most Western industrialized countries in 2001 may explain the drop in their income share in 2001 and its increase over the next 6 years until the start of the Global Financial Crisis. After falling back to its 2000 level in 2008, it grew over the last two years.

When we subdivide the top 1 per cent, we find that the lower half of this population (those in the 0.5 to 1.0 percentile) look more like those in the lower 9.5 percentiles of the top decile in their trend. Their share of income increased by 15.0 per cent between 1970 and 2010. They exhibited a small decline in income share between 1970 and 1985, a spike in income for 
1986 to 1988, a return to just slightly below their 1970 level in 1989 and modest growth since. They also exhibit some growth since 2008.

Only the top 0.1 to 0.5 percentile group and top 0.1 per cent substantially increased their share of income between 1970 and 2010-31.4 and 98.3 per cent respectively. Both groups experienced declines in income shares between 1970 and 1985, a substantial but temporary spike in income share for 1986 to 1988, and a fall in 1989, but to share levels slightly below those in 1970 for the 0.1 to 0.5 percentile group and appreciably higher for the top 0.1 per cent. Both groups experienced substantial increases in their share through 2000, a drop-off in share in 2001, followed by increases to just over their 2000 levels by the start of the Global Financial Crisis. They have also increased their share since 2008.

Even in our preferred series without realized capital gains there has been some increase in top incomes between 1970 and 2010. But we find that only the shares of those in the top 0.1 to 0.5 percentile and especially the top 0.1 per cent income groups increased substantially since 1970, and most of that increase occurred between 1985 and 2000.

\section{Evidence from Household Survey Data on Capital Gains}

Our top income series excluding taxable realized capital gains provides the most consistent data to measure levels and trends in top incomes. Here we make a broader point. Haig-Simons principles suggest that for horizontal equity reasons a tax base should capture income from all sources. If tax systems followed this ideal, they would be the perfect data source for measuring the share of income going to top income groups. But no income tax system includes income from all sources in its tax base. This is especially the case with respect to capital gains, since HaigSimons principles would suggest that taxes be placed on capital gains accrued from all assets 
each year. When capital gains are taxed, that tax is usually on realized capital gains. And it is not even on all sources of realized capital gains. So even after all assets purchased before September 19, 1985 have been realized and hence this eccentricity in Australian tax history has run its course, it is still not clear that just because it is there, that taxable realized capital gains is a useful measure of accrued capital gains.

Below we use data from the Household, Income and Labour Dynamics in Australia (HILDA) Survey to compare the size and distribution (across income groups) of taxable realized capital gains with the size and distribution of accrued capital gains on this type of taxable asset. We then compare them to the size and distribution of accrued capital gains on assets that are non-taxable (i.e. owner-occupied homes and superannuation funds). In keeping with the conventions of the top income literature, our sharing unit is the tax unit. ${ }^{29}$

HILDA does not specifically ask about capital gains. We impute taxable realized capital gains by first ranking all tax units in the ATO “1 per cent individual sample file” (produced for each tax year since 2003) into percentiles of ATO taxable (i.e. total assessable income less deductions) income and assigning the mean value of ATO total assessable income of each percentile to tax units ranked in a similar manner in the HILDA data. We could do this for all years since 2003. But we focus on tax years 2006 and 2009 because in addition to information on owner-occupied housing, which is reported each year, HILDA also collected a detailed wealth supplement in 2006 and 2010. Hence we are able to estimate accrued capital gains, both on

\footnotetext{
${ }^{29}$ HILDA is a nationally representative household panel study that began in 2001 with 13,969 respondents aged 15 years and over in 7,682 households. Face-to-face interviews are conducted annually with all household members aged 15 years and over. Detailed income information is collected from each respondent, which is aggregated by the data managers to produce annual aggregate income at both the person level and household level. See Wooden and Watson (2007) and Watson and Wooden (2010) for more HILDA details. To be consistent with the approach taken for tax record data, we restrict to persons aged 15 years and over and restrict non-capital gains income to components that are required to be reported to the tax office.
} 
assets that are taxable and those that are not. Conveniently, these are two particularly interesting years-2006 is the tax year prior to the Global Financial Crisis when capital gains were at a global business cycle peak, and the 2009 tax year is a much worse period for capital gains.

We base our estimates of accrued capital gains on owner-occupied housing on respondents' appraisals of their home's value. For a household that sells their home between one wave and the next, we approximate its capital gain in that year by the change in the ABS house price index over the last year for the capital city of the state of residence (ABS 2013b).

We base our estimates of accrued capital gains on non-owner-occupied housing, unincorporated businesses, equities and superannuation funds on asset holdings in 2006 and 2010, when detailed household wealth data was collected in the HILDA Survey. We estimate the accrued capital gains on non-owner-occupied housing using changes in the ABS house price index. We estimate accrued capital gains on unincorporated businesses and equity and superannuation fund holdings using the Australian Stock Exchange ASX200 share price index. (See the Appendix for a more detailed discussion of these imputations.) ${ }^{30}$

In Table 2 we report the share of capital gains held by top income groups in Australia across our four alternative measures of capital gains. In 2006 the top 1 per cent of tax units in the HILDA data received 20.9 per cent of the \$26.2 Billion in Taxable Realized Capital Gains. The top 10 per cent received 42.2 per cent thus showing the degree that this source of income is skewed to the top part of the income distribution. The top 1 per cent held an even larger share of Accrued Capital Gain on Taxable Assets—30.8 per cent. But more importantly this is a larger share of a much larger amount $\$ 362.5$ Billion. In contrast, the top 1 per cent held only 14.6 per

\footnotetext{
${ }^{30}$ For all three income variables, we have artificially restricted personal income inclusive of capital gains to be nonnegative. In Appendix Tables A6 and A7 we include negatives and find that the pattern of results evident in Tables 2 and 3 does not change.
} 
cent of the \$565.0 Billion of Accrued Capital Gains on Non-Taxable Assets. Overall they held 17.1 per cent of the $\$ 927.6$ Billion of Total Accrued Capital Gains. Accrued capital gains were much larger than realized capital gains in 2006, since realized capital gains are only a subset of accrued capital gains in 2006 plus the realization of accrued capital gains from previous years and in this peak year of the global business cycle, the accrued value of financial assets and owner-occupied housing were enormous relative to taxable realized capital gains. In contrast, in 2009 all four measures of capital gains were much diminished. The share of realized and accrued taxable assets held by the top 1 per cent fell substantially, while their share of accrued nontaxable assets rose somewhat.

Table 3 shows how these varying patterns of capital gains translate into our alternative measures of top incomes. Column 1 is our estimate of the share of income excluding capital gains in 2006 and in 2009. We find little change-10.6 per cent in 2006 and 10.5 per cent in 2009_-between these two years. When we include taxable realized capital gains in our income measure in column 2, the top 1 per cent income rises to 11.0 per cent in 2006; but falls to 10.5 per cent in 2009. This reflects the drop in total taxable realized capital gains in these two years that disproportionally occurred at the top end of the distribution reported in Table 2. But this drop is even more pronounced in column 3 of Table 3 when we use accrued capital gains on taxable assets rather than taxable realized capital gains in our income measure—a fall from 15.7 to 10.7 per cent. As can be seen in Table 2, this is so much larger both because the total dollar drop in accrued gains was so much larger than in realized gains and because it was more concentrated at the top end of the distribution. When we use accrued capital gains on assets that are not taxable (column 4 of Table 3), there is little change in the top 1 per cent share. This drops from 10.8 to 10.7 per cent despite the very large fall in the dollar value of these assets, because 
their distribution is much more evenly spread across the income distribution. These levels in both years are very close to those in column 1 which measures income without capital gains. Column 5, which includes all accrued capital gains, shows a fall from 13.0 to 10.8 per cent reflecting a blend of the previous two columns.

\section{Discussion}

Australia provides a cautionary tale of how comprehensive tax reform legislation has substantially altered the Australian top income series since 1985 and its comparability with earlier years, especially the Atkinson and Leigh (2007) series that does not separate taxable realized capital gains from other taxable income.

The huge short-run spike in top income shares reported by Atkinson and Leigh (2007) for 1987 and 1988 is a direct result of comprehensive tax reform that, as a side effect, distorted their "pre-tax income" top income series by the introduction of tax credits. But even in our corrected series we find a substantial rise in dividend income in those years, especially for the top 0.1 per cent. Here we suggest that tax avoidance rather than real changes in the economy may be at work. The government's decision to move from a classical to a 100 per cent imputation tax system was announced in 1985, but its effective reduction in the marginal tax on dividends only began on dividends received after the start of the 1987 tax year. This delay between the announcement and the drop in the marginal tax rate for dividends explains both the drop in the share of dividends in the portfolio of the top 0.1 per cent seen in 1986 and the dramatic rise in their share in 1987 and 1988, before falling in 1989 to a level above their share prior to 1985.

More important, what appears to be an increase in the share of income controlled by the top 1 per cent following the tax reforms-because of the rise in their dividend income, both in 
the short-run and even in the long-run-may to some degree simply be a fuller capturing of the earnings of companies in the Australian tax base. Prior to the 1985 tax reforms, companies were able to pay their shareholders in the form of capital gains that, if held for one year, were not taxed and hence not in the tax base. The 1985 tax reforms dramatically increased the share of earnings from companies captured in the personal income tax base by taxing these long-term capital gains, but did so only gradually on assets purchased after September 19, 1985. For this reason, we argue that the Atkinson and Leigh top income series including realized capital gains overstates the growth in share of income of the top 1 per cent after 1985 and we create a top income series excluding taxable realized capital gains.

However, some of the rise in dividends in our top income series excluding taxable realized capital gains comes from a behavioural change in the way that companies reward their stockholders. Not only was the marginal tax on dividends reduced but the marginal tax on capital gains was increased by the 1985 tax reforms, thus levelling the marginal tax rates on these alternative methods of distributing profits to shareholders. To the degree that profits that were "paid" to stockholders in untaxed long-term capital gains prior to the 1985 tax reforms were shifted to payments in dividends thereafter, this is another way that changes in tax rules and their effects on behaviour may be distorting the Australian top income series. The irony is that major tax reforms in 1985 that fixed a tax system "broken and beaten by an avalanche of avoidance, evasion, and minimisation” by broadening its income base and levelling the marginal rate across sources of income has had the side effect of substantially increasing the share of income Atkinson and Leigh capture in their top income measures, thereby resulting in their conflating this broadening of the tax base with a rise in the share of income held by top income groups. 
More broadly, the decline in the share of top incomes Atkinson and Leigh find in the 1970s and early 1980s may in part be explained by these top income groups' growing use of trusts to avoid the classical two-tier company tax system that the comprehensive tax reforms of 1985 ended. Tax avoidance behaviour that, together with the very rapid inflation that lowered the real income levels at which the top marginal tax rate on personal income kicked in, motivated these reforms (Australian Government 1985, Keating 1985). To the degree that top income groups were better able to shift their income into trusts and non-taxable capital gains prior to the 1985 tax reforms to avoid having their income counted in the tax base, the more tax-based studies like those of Atkinson and Leigh will also conflate increases in relative tax avoidance over this period by top income groups with a decline in their income shares.

What lessons can be drawn from this Australian case study? The changes in the Australian personal income tax base that we document occur to some degree in all the countries Atkinson, Piketty, and Saez (2011) review. The Australian experience is therefore unlikely to be unique. Hence, we advocate similar careful examination of tax system changes in all countries for which tax-records-based top income series are produced. While studies typically acknowledge at least some of the major changes in tax laws in the period they examine, they rarely attempt to correct for the inter-temporal inconsistencies that result from these changes. This is a potentially important limitation. At a minimum, country data series that contain a spike like the one we identify for Australia between 1985 and 1989 should document whether it is the result of a change in the economy or a change in tax rules that-either temporarily or over the long-run, or both—expands the personal income tax base. ${ }^{31}$

\footnotetext{
${ }^{31}$ Another example of a rarely controlled-for cliff caused by a tax law change can be found in the top income series excluding capital gains created for the U.S. by Piketty and Saez (2003). See Feenberg and Poterba (1993) and Slemrod (1996) for empirical analyses of the importance of the Reagan Era Tax Reform Act of 1986, which reduced
} 
The need for better documentation of differences in tax laws is even greater for those who use these data for cross-national comparisons. The world top incomes database the Paris School of Economics maintains on its website makes the start-up costs for cross-national comparisons lower. Yet there are a number of reasons to be concerned about the validity of such comparisons, in terms of both levels and trends. The tax treatment of capital gains is just one point of difference between countries. Countries that tax realized capital gains will capture a greater share of the income of high income groups. This is especially the case in Australia and the United States where realized capital gains on owner-occupied housing are not taxed and thus not included in the tax base. Another difference is in the taxation of the rental value of owneroccupied housing. Broadening the tax base in this way is likely to have the opposite effect, i.e., lowering the top income shares in these countries. There has been only limited work to date attempting to harmonize series across countries or otherwise account for the income base in country tax systems and other differences.

Finally, our findings using HILDA household survey data make a more general point with respect to capital gains and its effect on levels and trends of top income series. Armour, Burkhauser and Larrimore (2013) show that U.S. top income series are sensitive to the choice of measure chosen to capture capital gains. We find the same is the case in Australia. Given the sensitivity in our results across alternative measures of capital gains, it is not clear that including taxable realized capital gains as the measure of capital gains in the top income tax-based literature— just because it is there-is appropriate.

the highest marginal tax rate on personal income below the corporate tax rate and hence distorted subsequent changes in measured top income shares. 


\section{References}

ABS (Australian Bureau of Statistics) (2012) Australian System of National Accounts, 2011-12: Table 36. Household Income Account, Current Prices (Catalogue No. 5204.0).

ABS (Australian Bureau of Statistics) (2013a) Australian Demographic Statistics, Sep 2012: Table 59. Estimated Resident Population By Single Year Of Age, Australia (Catalogue No. 3101.0).

ABS (Australian Bureau of Statistics) (2013b) House Price Indexes: Eight Capital Cities (Catalogue No. 6046.0).

Armour, P., Burkhauser, R.V., and Larrimore, J. (2013) 'Deconstructing Income Inequality Measures: A Crosswalk from Market Income to Comprehensive Income’, American Economic Review Papers and Proceedings.

Asprey, K. (Chairman), Lloyd, J., Parsons, R., and Wood, K. (1975) Taxation Review Committee Full Report Canberra: Australian Government Publishing Service.

Atkinson, A.B. (2005), ‘Top Incomes in the UK over the Twentieth Century’, Journal of the Royal Statistical Society - Series A, 168, 325-43.

Atkinson, A.B., and Leigh, A. (2005), 'The Distribution of Top Incomes in Australia', Australian National University CEPR Discussion Paper No. 514, ANU, Canberra, ACT.

Atkinson, A.B., and Leigh, A. (2007). 'The Distribution of Top Incomes in Australia', Economic Record, 83(262): 247-61.

Atkinson, A.B., Piketty, T., and Saez, E. (2011) 'Top Incomes in the Long Run of History’, Journal of Economic Literature, 49:1 (2011), 3-71. 
Atkinson, A.B., and Piketty, T. (2007) Top Incomes over the Twentieth Century: A Contrast between Continental European and English Speaking Countries, New York: Oxford University Press.

Atkinson, A.B., and Piketty, T., eds. (2010) Top Incomes: A Global Perspective, Oxford and New York: Oxford University Press.

Australian Government. (1985) Reform of The Australian Tax System: Draft White Paper, Canberra (June): Australian Government Publishing Service.

Brandolini, A., and Smeeding, T.M. (2009) 'Income Inequality in Richer and OECD Countries', in Salverda, W., Nolan, B. and Smeeding, T.M. (eds.) The Oxford Handbook of Economic Inequality, Oxford: Oxford University Press.

Burkhauser, R.V., Larrimore, J., and Simon, K. (2012) 'A Second Opinion on the Economic Health of the Middle Class’, National Tax Journal 61(1), 7-22.

Commissioner of Taxation (1973-2013) in Australian Taxation Office Taxation statistics 1971-72 to 2010-11, Canberra: Australian Government Publishing Service.

CBO (Congressional Budget Office) (2011) Trends in the Distribution of Household Income between 1979 and 2007, U.S. Government Printing Office, Washington, DC.

CBO (Congressional Budget Office) (2012) The Distribution of Household Income and Federal Taxes, 2008 and 2009, U.S. Government Printing Office, Washington, DC. Supplemental data tables available online via: http://www.cbo.gov/publication/43373.

Feenberg, D.R., and Poterba, J.M. (1993) 'Income Inequality and the Incomes of Very High-Income Taxpayers: Evidence from Tax Returns', in J. Poterba (ed.) Tax Policy and the Economy, vol. 7. Cambridge: MIT Press, 145-77. 
Handley, J.C., and Maheswaran, K. (2008) 'A Measure of the Efficacy of the Australian Imputation Tax System’, The Economic Record, 84 (264) (March), 82-94.

Keating, P. (1985) Reform of the Australian Taxation System: Statement by the Treasurer, Canberra (September): Australian Government Publishing Service.

Leigh, A. (2009) 'Top Incomes’, in Salverda, W., Nolan, B. and Smeeding, T.M. (eds.) The Oxford Handbook of Economic Inequality, Oxford: Oxford University Press.

Piketty, T., and Saez, E. (2003) 'Income Inequality in the United States, 1913-1998', Quarterly Journal of Economics 118(1), 1-39.

Reinhardt, S., and Steel, L. (2006), ‘A Brief History of Australia’s Tax System’, paper presented to the 22nd APEC Finance Ministers' Economic Roundup, Winter, pp. 1-16 (Australian Government—The Treasury).

Slemrod, J. (1996) 'High Income Families and the Tax Changes of the 1980s: the Anatomy of Behavioural Response', in M. Feldstein and J. Poterba (eds.) Empirical Foundations of Household Taxation. Chicago: University of Chicago Press.

Watson, N., and Wooden, M. (2010) 'The HILDA Survey Progress and Future Developments', The Australian Economic Review 43(3): 326-336.

Wooden, M., and Watson, N. (2007) 'The HILDA Survey and its Contribution to Economic and Social Research (So Far)’ The Economic Record 83(261): 208-231. 


\section{Figures and tables}

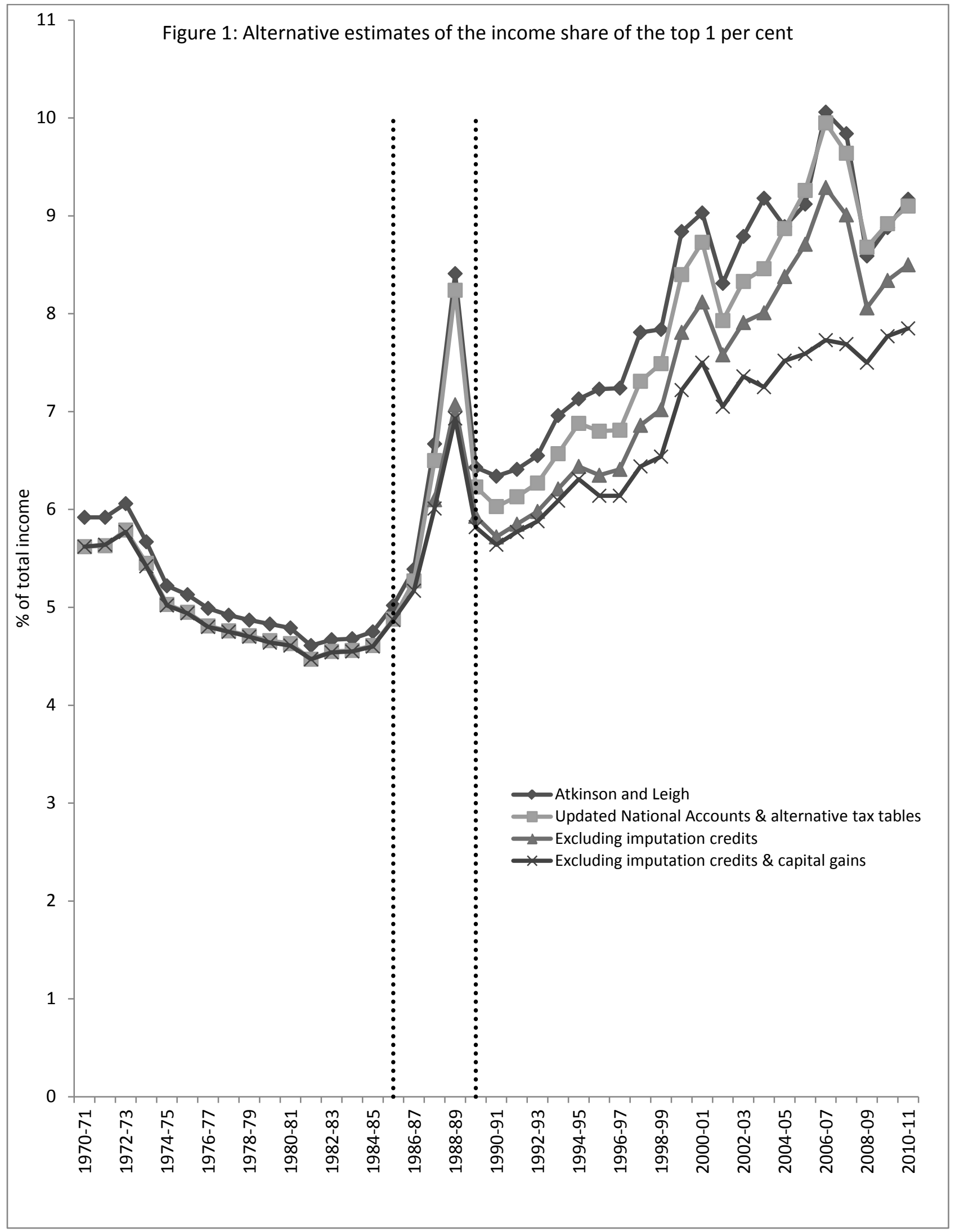

Source: Authors' calculations. 


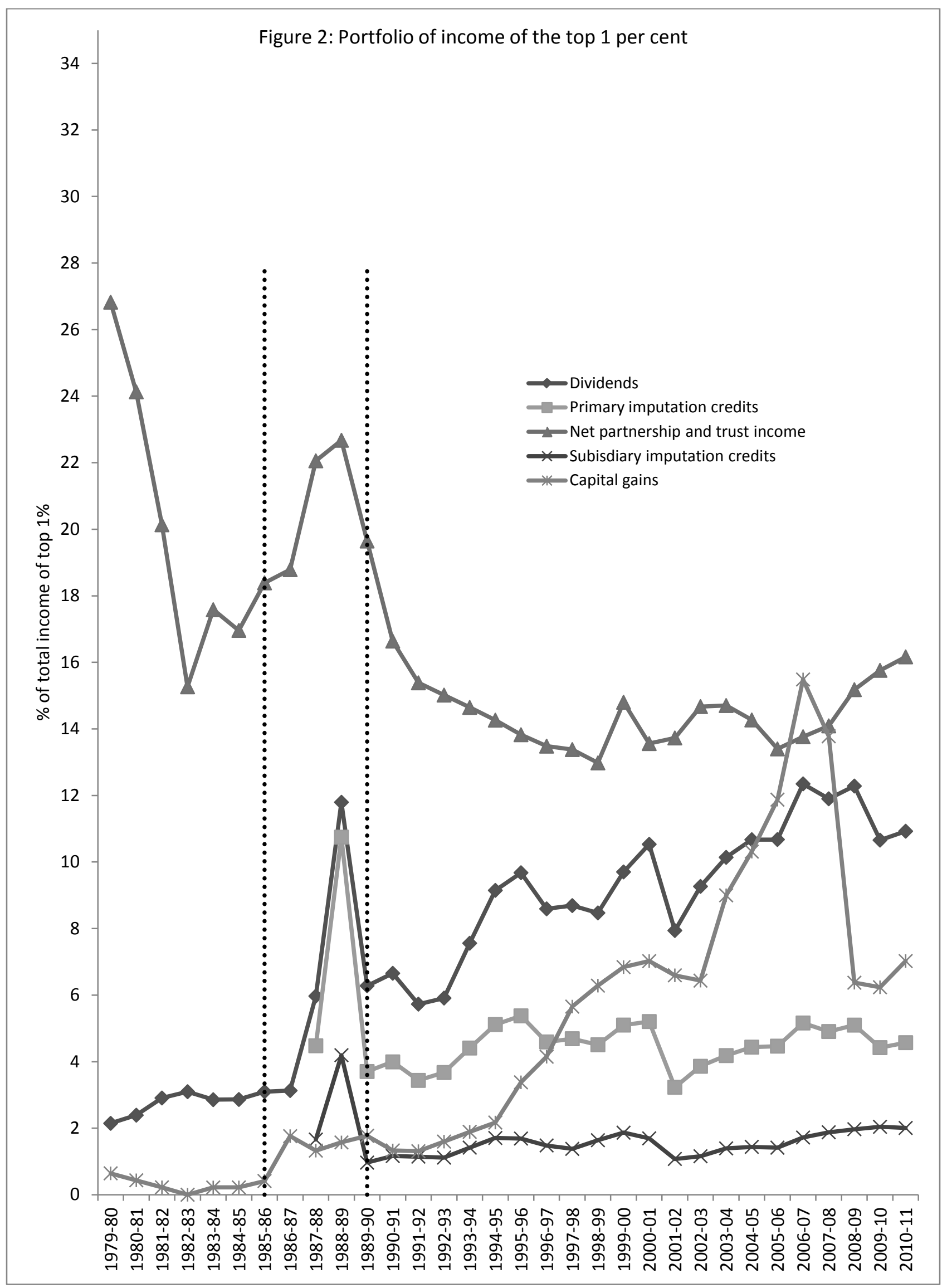

Source: Authors' calculations. 


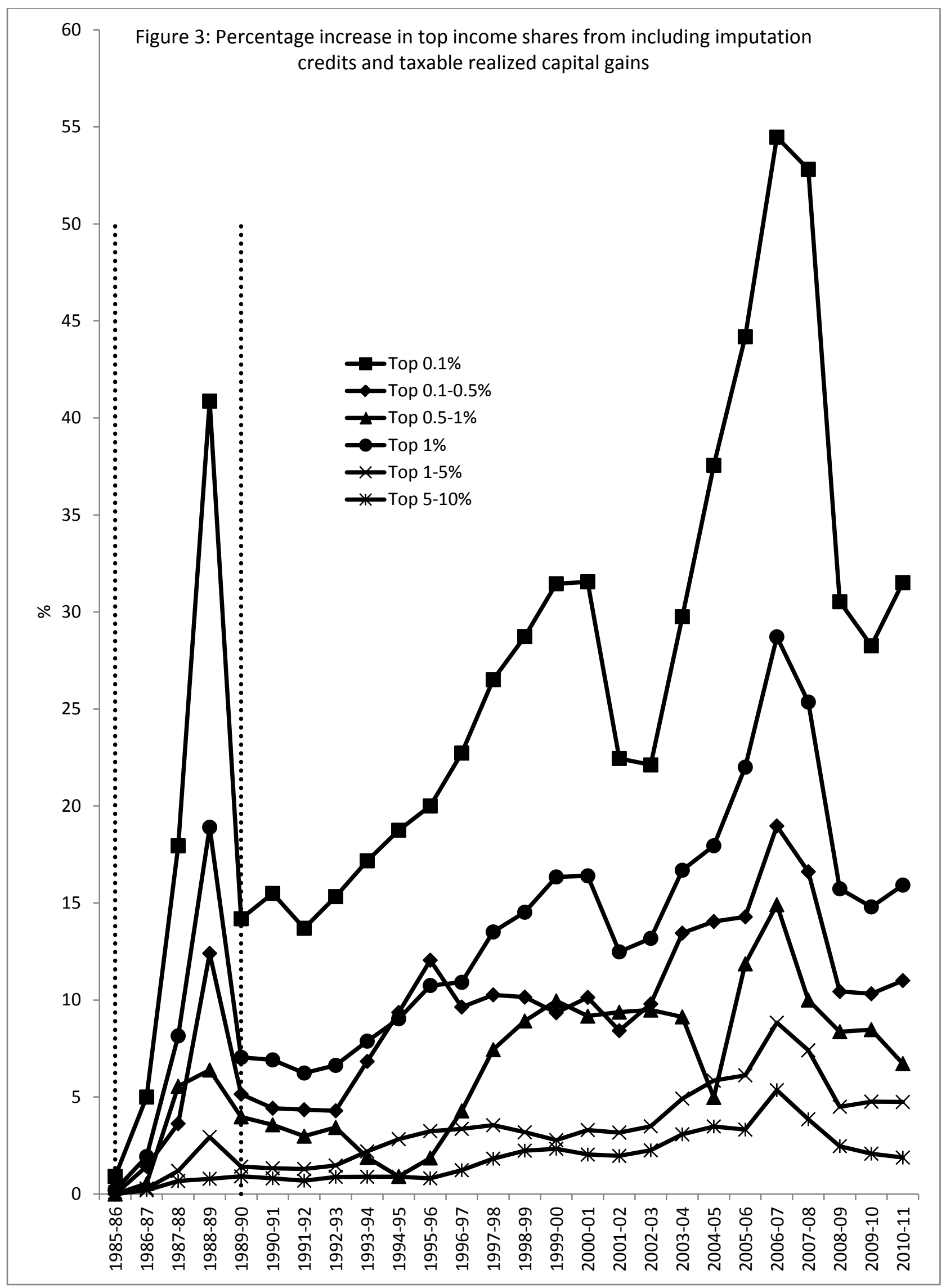

Source: Authors' calculations. The percentage increase is equal to the difference between income share (2) and income share (4), expressed as a percentage of income share (4). 


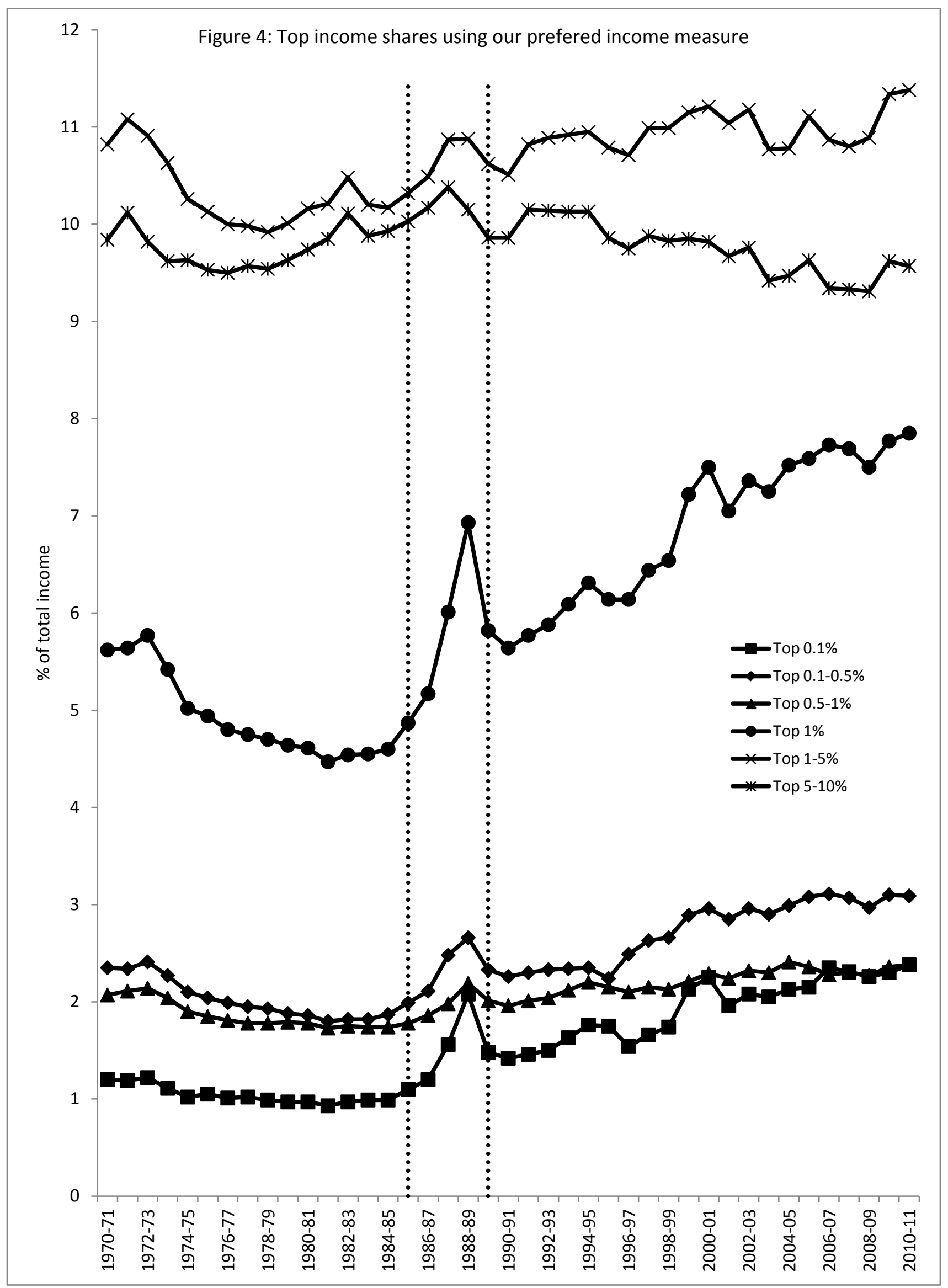

Source: Authors' calculations. 
Table 1: Share of dividends and tax credits in portfolios of top income groups, 1985 to 1989 (\%)

\begin{tabular}{|c|c|c|c|c|c|c|c|c|c|c|c|c|c|c|}
\hline & \multirow{2}{*}{$\begin{array}{c}1985-86 \\
\text { Dividends } \\
\end{array}$} & \multirow{2}{*}{$\begin{array}{r}1986-87 \\
\text { Dividends } \\
\end{array}$} & \multicolumn{4}{|c|}{$1987-88$} & \multicolumn{4}{|c|}{ 1988-89 } & \multicolumn{4}{|c|}{$1989-90$} \\
\hline & & & Dividends & $\begin{array}{c}\text { Primary } \\
\text { imputation } \\
\text { credits }\end{array}$ & $\begin{array}{c}\text { Subsidiary } \\
\text { imputation } \\
\text { credits }\end{array}$ & Total & Dividends & $\begin{array}{c}\text { Primary } \\
\text { imputation } \\
\text { credits }\end{array}$ & $\begin{array}{c}\text { Subsidiary } \\
\text { imputation } \\
\text { credits } \\
\end{array}$ & Total & Dividends & $\begin{array}{c}\text { Primary } \\
\text { imputation } \\
\text { credits }\end{array}$ & $\begin{array}{c}\text { Subsidiary } \\
\text { imputation } \\
\text { credits }\end{array}$ & Total \\
\hline Top $0.1 \%$ & 5.4 & 4.5 & 10.6 & 4.9 & 7.0 & 22.5 & 20.2 & 18.3 & 9.6 & 48.2 & 10.4 & 6.1 & 1.7 & 18.3 \\
\hline Top $0.1-0.5 \%$ & 2.8 & 3.1 & 6.0 & 6.0 & 0.0 & 12.1 & 11.2 & 10.1 & 2.5 & 23.8 & 6.7 & 4.0 & 1.0 & 11.7 \\
\hline Top $0.5-1 \%$ & 2.0 & 2.4 & 2.6 & 2.0 & 0.0 & 4.6 & 3.3 & 2.8 & 0.6 & 6.7 & 3.4 & 1.9 & 0.5 & 5.8 \\
\hline Top 1\% & 3.1 & 3.1 & 6.0 & 4.5 & 1.7 & 12.2 & 11.8 & 10.8 & 4.2 & 26.8 & 6.3 & 3.7 & 1.0 & 11.0 \\
\hline
\end{tabular}

Source: Authors’ calculations.

Table 2: Distribution of alternative measures of capital gains, 2006 and 2009

\begin{tabular}{|c|c|c|c|c|c|c|c|c|}
\hline & \multicolumn{2}{|c|}{ Realized taxable capital gains } & \multicolumn{2}{|c|}{ Accrued taxable capital gains } & \multicolumn{2}{|c|}{$\begin{array}{c}\text { Accrued non-taxable capital } \\
\text { gains }\end{array}$} & \multicolumn{2}{|c|}{$\begin{array}{c}\text { Accrued taxable and } \\
\text { non-taxable capital gains }\end{array}$} \\
\hline & $\$$ & $(\%)$ & $\$$ & $(\%)$ & $\$$ & $(\%)$ & $\$$ & $(\%)$ \\
\hline \multicolumn{9}{|l|}{ 2006-07 } \\
\hline \multicolumn{9}{|c|}{ Location in income distribution } \\
\hline Bottom 90\% & 1,054 & 57.7 & 6,522 & 25.8 & 18,666 & 47.3 & 28,180 & 43.5 \\
\hline Percentiles 91 to 95 & 2,336 & 6.8 & 60,806 & 13.3 & 113,379 & 16.0 & 176,916 & 15.2 \\
\hline Percentiles 96 to 99 & 5,986 & 14.5 & 171,055 & 30.1 & 196,802 & 22.1 & 352,033 & 24.1 \\
\hline Top percentile & 34,727 & 20.9 & 707,523 & 30.8 & 518,277 & 14.6 & 999,406 & 17.1 \\
\hline Total & $26,229,391,372$ & 100.0 & $362,514,535,198$ & 100.0 & $565,036,702,409$ & 100.0 & $927,551,236,616$ & 100.0 \\
\hline Mean & 1,648 & & 22,772 & & 35,494 & & 58,267 & \\
\hline Median & 1,037 & & 0 & & 6,833 & & 14,327 & \\
\hline \multicolumn{9}{|l|}{$2009-10$} \\
\hline \multicolumn{9}{|c|}{ Location in income distribution } \\
\hline Bottom 90\% & 385 & 68.3 & 2,027 & 37.8 & 7,637 & 41.8 & 10,463 & 44.3 \\
\hline Percentiles 91 to 95 & 545 & 5.1 & 18,096 & 18.8 & 50,123 & 15.2 & 62,509 & 14.6 \\
\hline Percentiles 96 to 99 & 1,963 & 15.4 & 30,796 & 25.6 & 103,035 & 25.1 & 130,859 & 24.6 \\
\hline Top percentile & 5,700 & 11.2 & 86,849 & 17.8 & 295,979 & 17.9 & 351,798 & 16.5 \\
\hline Total & $8,669,889,477$ & 100.0 & $82,186,727,070$ & 100.0 & $280,353,965,813$ & 100.0 & $362,540,692,440$ & 100.0 \\
\hline Mean & 509 & & 4,822 & & 16,447 & & 21,269 & \\
\hline Median & 359 & & 0 & & 0 & & 0 & \\
\hline
\end{tabular}

Notes: Negative capital gains are set equal to zero. For capital gains by location in the income distribution, individuals are ordered in each column by the income measure indicated in the column heading. Dollar amounts are in 2009-10 Australian dollars.

Sources: Authors' calculations using data from Release 11.0 of the HILDA Survey confidentialised unit record file and taxation data from Taxation Statistics (various years). 
Table 3: Distribution of income including alternative measures of capital gains, 2006 and 2009

\begin{tabular}{|c|c|c|c|c|c|c|c|c|c|c|}
\hline & \multicolumn{2}{|c|}{$\begin{array}{l}\text { Income without } \\
\text { capital gains }\end{array}$} & \multicolumn{2}{|c|}{$\begin{array}{c}\text { Income with realized taxable } \\
\text { capital gains }\end{array}$} & \multicolumn{2}{|c|}{$\begin{array}{c}\text { Income with accrued taxable } \\
\text { capital gains }\end{array}$} & \multicolumn{2}{|c|}{$\begin{array}{c}\text { Income with accrued } \\
\text { non-taxable capital gains }\end{array}$} & \multicolumn{2}{|c|}{$\begin{array}{l}\text { Income with accrued taxable } \\
\& \text { non-taxable capital gains }\end{array}$} \\
\hline & $\$$ & $(\%)$ & $\$$ & $(\%)$ & $\$$ & (\%) & $\$$ & $(\%)$ & $\$$ & $(\%)$ \\
\hline \multicolumn{11}{|l|}{ 2006-07 } \\
\hline \multicolumn{11}{|c|}{ Location in income distribution } \\
\hline Bottom 90\% & 29,170 & 63.7 & 30,225 & 63.5 & 38,078 & 53.5 & 50,685 & 59.4 & 61,002 & 55.1 \\
\hline Percentiles 91 to 95 & 97,515 & 11.3 & 99,851 & 11.1 & 155,854 & 12.1 & 200,468 & 13.1 & 262,520 & 13.2 \\
\hline Percentiles 96 to 99 & 147,899 & 14.3 & 153,884 & 14.3 & 299,539 & 18.7 & 322,104 & 16.7 & 465,219 & 18.7 \\
\hline Top percentile & 441,509 & 10.6 & 476,236 & 11.0 & $1,009,953$ & 15.7 & 830,369 & 10.8 & $1,293,981$ & 13.0 \\
\hline Total & $657,294,375,852$ & 100.0 & $683,523,765,745$ & 100.0 & $1,019,808,907,295$ & 100.0 & $1,222,331,073,521$ & 100.0 & $1,584,845,606,549$ & 100.0 \\
\hline Mean & 41,290 & & 42,937 & & 64,062 & & 76,784 & & 99,556 & \\
\hline Median & 29,233 & & 31,208 & & 37,211 & & 47,810 & & 54,576 & \\
\hline \multicolumn{11}{|l|}{$2009-10$} \\
\hline \multicolumn{11}{|c|}{ Location in income distribution } \\
\hline Bottom 90\% & 30,104 & 63.7 & 30,489 & 63.7 & 32,647 & 61.8 & 39,974 & 60.8 & 42,973 & 60.5 \\
\hline Percentiles 91 to 95 & 102,568 & 11.3 & 103,113 & 11.3 & 116,539 & 12.3 & 144,664 & 12.2 & 158,530 & 12.3 \\
\hline Percentiles 96 to 99 & 155,032 & 14.5 & 156,996 & 14.5 & 180,211 & 15.2 & 239,665 & 16.2 & 262,666 & 16.4 \\
\hline Top percentile & 449,227 & 10.5 & 454,927 & 10.5 & 514,755 & 10.7 & 637,765 & 10.7 & 691,214 & 10.8 \\
\hline Total & $727,831,670,558$ & 100.0 & $736,501,561,146$ & 100.0 & $810,018,397,253$ & 100.0 & $1,008,185,635,605$ & 100.0 & $1,090,372,362,213$ & 100.0 \\
\hline Mean & 42,699 & & 43,208 & & 47,521 & & 59,147 & & 63,969 & \\
\hline Median & 29,996 & & 30,644 & & 31,996 & & 39,566 & & 41,696 & \\
\hline
\end{tabular}

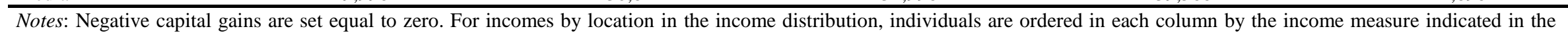
column heading. Dollar amounts are in 2009-10 Australian dollars.

Sources: Authors' calculations using Release 11.0 of the HILDA Survey confidentialised unit record file and taxation data from Taxation Statistics (various years). 


\section{Appendix Tables and Figures}

Appendix Table A1: Atkinson and Leigh top income shares (\%)

\begin{tabular}{|c|c|c|c|c|c|c|c|}
\hline Year & Top $10 \%$ & Top 5\% & Top 1\% & Top $0.5 \%$ & Top $0.1 \%$ & Top $0.05 \%$ & Top $0.01 \%$ \\
\hline $1970-71$ & 27.65 & 17.30 & 5.92 & 3.74 & 1.26 & 0.79 & 0.27 \\
\hline $1971-72$ & 28.24 & 17.59 & 5.92 & 3.70 & 1.25 & 0.78 & 0.27 \\
\hline $1972-73$ & 27.80 & 17.50 & 6.06 & 3.81 & 1.29 & 0.81 & 0.28 \\
\hline $1973-74$ & 26.74 & 16.73 & 5.67 & 3.54 & 1.17 & 0.73 & 0.24 \\
\hline $1974-75$ & 25.87 & 15.87 & 5.22 & 3.24 & 1.06 & 0.65 & 0.21 \\
\hline $1975-76$ & 25.54 & 15.65 & 5.13 & 3.22 & 1.10 & 0.68 & 0.23 \\
\hline $1976-77$ & 25.20 & 15.35 & 4.99 & 3.11 & 1.05 & 0.65 & 0.21 \\
\hline $1977-78$ & 25.15 & 15.25 & 4.92 & 3.08 & 1.06 & 0.67 & - \\
\hline $1978-79$ & 25.01 & 15.14 & 4.87 & 3.02 & 1.03 & 0.65 & - \\
\hline $1979-80$ & 25.17 & 15.20 & 4.83 & 2.97 & 1.02 & 0.65 & - \\
\hline 1980-81 & 25.39 & 15.31 & 4.79 & 2.95 & 1.02 & 0.66 & - \\
\hline 1981-82 & 25.31 & 15.15 & 4.61 & 2.83 & 0.96 & 0.62 & - \\
\hline 1982-83 & 25.82 & 15.44 & 4.67 & 2.87 & 1.00 & 0.63 & - \\
\hline 1983-84 & 25.32 & 15.16 & 4.68 & 2.89 & 1.02 & 0.66 & - \\
\hline 1984-85 & 25.50 & 15.25 & 4.75 & 2.96 & 1.03 & - & - \\
\hline $1985-86$ & 25.93 & 15.63 & 5.02 & 3.19 & 1.14 & 0.75 & 0.35 \\
\hline 1986-87 & 26.61 & 16.17 & 5.39 & 3.48 & 1.29 & 0.85 & 0.36 \\
\hline $1987-88$ & 28.66 & 17.94 & 6.67 & 4.53 & 1.89 & 1.41 & 0.60 \\
\hline 1988-89 & 30.28 & 19.84 & 8.41 & 6.04 & 2.99 & 2.13 & 0.98 \\
\hline $1989-90$ & 27.64 & 17.46 & 6.43 & 4.29 & 1.79 & 1.31 & 0.51 \\
\hline 1990-91 & 27.66 & 17.37 & 6.34 & 4.24 & 1.79 & 1.33 & 0.55 \\
\hline 1991-92 & 28.22 & 17.70 & 6.41 & 4.28 & 1.81 & 1.35 & 0.57 \\
\hline $1992-93$ & 28.52 & 17.95 & 6.55 & 4.38 & 1.87 & 1.37 & 0.57 \\
\hline 1993-94 & 29.40 & 18.66 & 6.96 & 4.69 & 2.08 & 1.46 & 0.61 \\
\hline 1994-95 & 29.42 & 18.87 & 7.13 & 5.10 & 2.56 & 1.65 & 0.71 \\
\hline 1995-96 & 29.13 & 18.76 & 7.23 & 4.95 & 2.14 & 1.52 & 0.73 \\
\hline 1996-97 & 29.16 & 18.77 & 7.24 & 4.93 & 2.07 & 1.44 & 0.65 \\
\hline $1997-98$ & 30.41 & 19.73 & 7.81 & 5.38 & 2.32 & 1.64 & 0.75 \\
\hline 1998-99 & 30.11 & 19.63 & 7.84 & 5.43 & 2.37 & 1.67 & 0.76 \\
\hline 1999-00 & 31.48 & 20.95 & 8.84 & 6.29 & 3.04 & 2.15 & - \\
\hline 2000-01 & 31.28 & 20.98 & 9.03 & 6.44 & 3.06 & 2.24 & - \\
\hline 2001-02 & 30.61 & 20.33 & 8.31 & 5.75 & 2.51 & 1.75 & - \\
\hline 2002-03 & 31.34 & 20.90 & 8.79 & 6.11 & 2.68 & 1.87 & - \\
\hline 2003-04 & 32.04 & 21.49 & 9.18 & 6.46 & 2.89 & 2.05 & - \\
\hline 2004-05 & 30.08 & 20.32 & 8.89 & 6.35 & 2.93 & 2.11 & - \\
\hline 2005-06 & 30.54 & 20.72 & 9.12 & 6.52 & 3.05 & 2.19 & - \\
\hline 2006-07 & 31.81 & 21.91 & 10.06 & 7.38 & 3.65 & 2.66 & - \\
\hline 2007-08 & 31.51 & 21.61 & 9.84 & 7.23 & 3.58 & 2.63 & - \\
\hline 2008-09 & 29.34 & 19.85 & 8.59 & 6.15 & 2.91 & 2.11 & - \\
\hline 2009-10 & 30.56 & 20.69 & 8.88 & 6.33 & 2.93 & 2.09 & - \\
\hline 2010-11 & 30.98 & 21.10 & 9.17 & 6.59 & 3.15 & 2.29 & - \\
\hline
\end{tabular}

Source: Authors' calculations. 
Appendix Table A1.2: Top income shares using updated tax tables that distinguish components of income (\%)

\begin{tabular}{|c|c|c|c|c|c|c|c|}
\hline Year & Top 10\% & Top 5\% & Top 1\% & Top $0.5 \%$ & Top $0.1 \%$ & Top $0.05 \%$ & Top $0.01 \%$ \\
\hline $1970-71$ & 27.65 & 17.30 & 5.92 & 3.74 & 1.26 & 0.79 & 0.27 \\
\hline $1971-72$ & 28.24 & 17.59 & 5.92 & 3.70 & 1.25 & 0.78 & 0.27 \\
\hline $1972-73$ & 27.80 & 17.50 & 6.06 & 3.81 & 1.29 & 0.81 & 0.28 \\
\hline $1973-74$ & 26.74 & 16.73 & 5.67 & 3.54 & 1.17 & 0.73 & 0.24 \\
\hline $1974-75$ & 25.87 & 15.87 & 5.22 & 3.24 & 1.06 & 0.65 & 0.21 \\
\hline $1975-76$ & 25.54 & 15.65 & 5.13 & 3.22 & 1.10 & 0.68 & 0.23 \\
\hline 1976-77 & 25.20 & 15.35 & 4.99 & 3.11 & 1.05 & 0.65 & 0.21 \\
\hline $1977-78$ & 25.15 & 15.25 & 4.92 & 3.08 & 1.06 & 0.67 & - \\
\hline $1978-79$ & 25.01 & 15.14 & 4.87 & 3.02 & 1.03 & 0.65 & - \\
\hline 1979-80 & 25.17 & 15.20 & 4.83 & 2.97 & 1.02 & 0.65 & - \\
\hline 1980-81 & 25.39 & 15.31 & 4.79 & 2.95 & 1.02 & 0.66 & - \\
\hline 1981-82 & 25.31 & 15.15 & 4.61 & 2.83 & 0.96 & 0.62 & - \\
\hline 1982-83 & 25.82 & 15.44 & 4.67 & 2.87 & 1.00 & 0.63 & - \\
\hline 1983-84 & 25.32 & 15.16 & 4.68 & 2.89 & 1.02 & 0.66 & - \\
\hline 1984-85 & 25.50 & 15.25 & 4.75 & 2.96 & 1.03 & - & - \\
\hline $1985-86$ & 25.93 & 15.63 & 5.02 & 3.19 & 1.14 & 0.75 & 0.35 \\
\hline 1986-87 & 26.61 & 16.17 & 5.39 & 3.48 & 1.29 & 0.85 & 0.36 \\
\hline 1987-88 & 28.66 & 17.94 & 6.67 & 4.53 & 1.89 & 1.41 & 0.60 \\
\hline 1988-89 & 30.28 & 19.84 & 8.41 & 6.04 & 2.99 & 2.13 & 0.98 \\
\hline 1989-90 & 27.58 & 17.40 & 6.37 & 4.23 & 1.73 & 1.25 & 0.46 \\
\hline 1990-91 & 27.58 & 17.28 & 6.25 & 4.15 & 1.70 & 1.24 & 0.46 \\
\hline 1991-92 & 28.12 & 17.59 & 6.31 & 4.18 & 1.71 & 1.25 & 0.47 \\
\hline 1992-93 & 28.51 & 17.93 & 6.49 & 4.31 & 1.79 & 1.28 & 0.48 \\
\hline 1993-94 & 29.00 & 18.39 & 6.82 & 4.57 & 1.98 & 1.36 & 0.53 \\
\hline 1994-95 & 29.49 & 18.86 & 7.15 & 4.84 & 2.17 & 1.44 & 0.58 \\
\hline 1995-96 & 29.01 & 18.67 & 7.08 & 4.80 & 2.18 & 1.44 & 0.59 \\
\hline 1996-97 & 29.07 & 18.73 & 7.14 & 4.84 & 1.98 & 1.36 & 0.56 \\
\hline $1997-98$ & 30.23 & 19.65 & 7.69 & 5.26 & 2.21 & 1.52 & 0.63 \\
\hline 1998-99 & 30.04 & 19.58 & 7.79 & 5.38 & 2.33 & 1.62 & 0.70 \\
\hline 1999-00 & 31.50 & 20.89 & 8.83 & 6.27 & 2.95 & 2.12 & - \\
\hline 2000-01 & 31.37 & 21.00 & 9.03 & 6.44 & 3.06 & 2.24 & - \\
\hline 2001-02 & 30.57 & 20.24 & 8.31 & 5.75 & 2.51 & 1.75 & - \\
\hline 2002-03 & 31.53 & 21.00 & 8.79 & 6.11 & 2.68 & 1.87 & - \\
\hline 2003-04 & 32.01 & 21.46 & 9.19 & 6.46 & 2.89 & 2.05 & - \\
\hline 2004-05 & 30.13 & 20.31 & 8.88 & 6.35 & 2.93 & 2.11 & - \\
\hline 2005-06 & 30.51 & 20.71 & 9.11 & 6.51 & 3.05 & 2.19 & - \\
\hline 2006-07 & 31.81 & 21.92 & 10.01 & 7.38 & 3.65 & 2.66 & - \\
\hline 2007-08 & 31.46 & 21.60 & 9.80 & 7.23 & 3.58 & 2.63 & \\
\hline 2008-09 & 29.26 & 19.82 & 8.58 & 6.15 & 2.91 & 2.11 & - \\
\hline 2009-10 & 30.51 & 20.71 & 8.88 & 6.33 & 2.93 & 2.09 & - \\
\hline 2010-11 & 31.20 & 21.30 & 9.21 & 6.64 & 3.17 & 2.31 & - \\
\hline
\end{tabular}

Source: Authors' calculations. 
Appendix Table A2: Top income shares using updated population and National Accounts data and updated tax tables that distinguish components of income (\%)

\begin{tabular}{|c|c|c|c|c|c|c|c|}
\hline Year & Top $10 \%$ & Top 5\% & Top 1\% & Top 0.5\% & Top $0.1 \%$ & Top $0.05 \%$ & Top $0.01 \%$ \\
\hline $1970-71$ & 26.29 & 16.45 & 5.62 & 3.55 & 1.20 & 0.75 & 0.26 \\
\hline $1971-72$ & 26.82 & 16.71 & 5.63 & 3.52 & 1.18 & 0.74 & 0.25 \\
\hline $1972-73$ & 26.52 & 16.70 & 5.79 & 3.64 & 1.23 & 0.77 & 0.27 \\
\hline $1973-74$ & 25.71 & 16.09 & 5.45 & 3.40 & 1.12 & 0.70 & 0.23 \\
\hline $1974-75$ & 24.92 & 15.29 & 5.03 & 3.13 & 1.02 & 0.63 & 0.21 \\
\hline $1975-76$ & 24.62 & 15.09 & 4.95 & 3.10 & 1.06 & 0.66 & 0.22 \\
\hline $1976-77$ & 24.31 & 14.81 & 4.81 & 3.00 & 1.01 & 0.62 & 0.20 \\
\hline $1977-78$ & 24.31 & 14.74 & 4.76 & 2.98 & 1.02 & 0.65 & - \\
\hline $1978-79$ & 24.17 & 14.64 & 4.71 & 2.92 & 0.99 & 0.63 & - \\
\hline $1979-80$ & 24.33 & 14.69 & 4.66 & 2.87 & 0.98 & 0.63 & - \\
\hline $1980-81$ & 24.55 & 14.80 & 4.63 & 2.85 & 0.98 & 0.64 & - \\
\hline 1981-82 & 24.53 & 14.68 & 4.47 & 2.74 & 0.93 & 0.60 & - \\
\hline $1982-83$ & 25.15 & 15.03 & 4.55 & 2.79 & 0.97 & 0.61 & - \\
\hline $1983-84$ & 24.64 & 14.76 & 4.56 & 2.82 & 0.99 & 0.64 & - \\
\hline 1984-85 & 24.71 & 14.78 & 4.61 & 2.87 & 1.00 & - & - \\
\hline $1985-86$ & 25.24 & 15.21 & 4.88 & 3.10 & 1.11 & 0.73 & 0.34 \\
\hline $1986-87$ & 25.97 & 15.79 & 5.27 & 3.39 & 1.26 & 0.83 & 0.35 \\
\hline 1987-88 & 27.95 & 17.50 & 6.50 & 4.41 & 1.84 & 1.38 & 0.58 \\
\hline 1988-89 & 29.67 & 19.44 & 8.24 & 5.91 & 2.93 & 2.08 & 0.96 \\
\hline $1989-90$ & 26.95 & 17.00 & 6.23 & 4.14 & 1.69 & 1.22 & 0.45 \\
\hline $1990-91$ & 26.61 & 16.67 & 6.03 & 4.00 & 1.64 & 1.20 & 0.45 \\
\hline $1991-92$ & 27.31 & 17.08 & 6.13 & 4.06 & 1.66 & 1.21 & 0.46 \\
\hline 1992-93 & 27.55 & 17.32 & 6.27 & 4.17 & 1.73 & 1.24 & 0.46 \\
\hline $1993-94$ & 27.95 & 17.73 & 6.57 & 4.41 & 1.91 & 1.31 & 0.51 \\
\hline 1994-95 & 28.36 & 18.14 & 6.88 & 4.65 & 2.09 & 1.39 & 0.56 \\
\hline $1995-96$ & 27.87 & 17.93 & 6.80 & 4.61 & 2.10 & 1.39 & 0.57 \\
\hline $1996-97$ & 27.75 & 17.88 & 6.81 & 4.62 & 1.89 & 1.30 & 0.53 \\
\hline 1997-98 & 28.75 & 18.69 & 7.31 & 5.00 & 2.10 & 1.45 & 0.60 \\
\hline 1998-99 & 28.89 & 18.83 & 7.49 & 5.17 & 2.24 & 1.56 & 0.68 \\
\hline 1999-00 & 29.95 & 19.86 & 8.40 & 5.97 & 2.80 & 2.02 & - \\
\hline 2000-01 & 30.33 & 20.30 & 8.73 & 6.22 & 2.96 & 2.16 & - \\
\hline 2001-02 & 29.18 & 19.32 & 7.93 & 5.49 & 2.40 & 1.67 & - \\
\hline 2002-03 & 29.88 & 19.90 & 8.33 & 5.79 & 2.54 & 1.77 & - \\
\hline 2003-04 & 29.48 & 19.76 & 8.46 & 5.95 & 2.66 & 1.89 & - \\
\hline 2004-05 & 30.08 & 20.28 & 8.87 & 6.34 & 2.93 & 2.10 & - \\
\hline 2005-06 & 31.00 & 21.05 & 9.26 & 6.62 & 3.10 & 2.22 & - \\
\hline 2006-07 & 31.62 & 21.79 & 9.95 & 7.34 & 3.63 & 2.64 & - \\
\hline 2007-08 & 30.93 & 21.24 & 9.64 & 7.11 & 3.53 & 2.59 & - \\
\hline 2008-09 & 29.60 & 20.06 & 8.68 & 6.23 & 2.95 & 2.14 & - \\
\hline 2009-10 & 30.62 & 20.79 & 8.92 & 6.36 & 2.95 & 2.10 & - \\
\hline 2010-11 & 30.77 & 21.02 & 9.10 & 6.56 & 3.13 & 2.28 & - \\
\hline
\end{tabular}

Source: Authors' calculations. 
Appendix Table A3: Top income shares using updated data and tax tables and excluding dividend imputation credits (\%)

\begin{tabular}{|c|c|c|c|c|c|c|c|}
\hline Year & Top 10\% & Top 5\% & Top 1\% & Top $0.5 \%$ & Top $0.1 \%$ & Top $0.05 \%$ & Top $0.01 \%$ \\
\hline $1970-71$ & 26.29 & 16.45 & 5.62 & 3.55 & 1.20 & 0.75 & 0.26 \\
\hline $1971-72$ & 26.82 & 16.71 & 5.63 & 3.52 & 1.18 & 0.74 & 0.25 \\
\hline $1972-73$ & 26.52 & 16.70 & 5.79 & 3.64 & 1.23 & 0.77 & 0.27 \\
\hline $1973-74$ & 25.71 & 16.09 & 5.45 & 3.40 & 1.12 & 0.70 & 0.23 \\
\hline $1974-75$ & 24.92 & 15.29 & 5.03 & 3.13 & 1.02 & 0.63 & 0.21 \\
\hline $1975-76$ & 24.62 & 15.09 & 4.95 & 3.10 & 1.06 & 0.66 & 0.22 \\
\hline 1976-77 & 24.31 & 14.81 & 4.81 & 3.00 & 1.01 & 0.62 & 0.20 \\
\hline $1977-78$ & 24.31 & 14.74 & 4.76 & 2.98 & 1.02 & 0.65 & - \\
\hline 1978-79 & 24.17 & 14.64 & 4.71 & 2.92 & 0.99 & 0.63 & - \\
\hline $1979-80$ & 24.33 & 14.69 & 4.66 & 2.87 & 0.98 & 0.63 & - \\
\hline 1980-81 & 24.55 & 14.80 & 4.63 & 2.85 & 0.98 & 0.64 & - \\
\hline 1981-82 & 24.53 & 14.68 & 4.47 & 2.74 & 0.93 & 0.60 & - \\
\hline 1982-83 & 25.15 & 15.03 & 4.55 & 2.79 & 0.97 & 0.61 & - \\
\hline 1983-84 & 24.64 & 14.76 & 4.56 & 2.82 & 0.99 & 0.64 & - \\
\hline 1984-85 & 24.71 & 14.78 & 4.61 & 2.87 & 1.00 & - & - \\
\hline $1985-86$ & 25.24 & 15.21 & 4.88 & 3.10 & 1.11 & 0.73 & 0.34 \\
\hline 1986-87 & 25.97 & 15.79 & 5.27 & 3.39 & 1.26 & 0.83 & 0.35 \\
\hline 1987-88 & 27.42 & 17.01 & 6.10 & 4.10 & 1.60 & 1.17 & 0.48 \\
\hline 1988-89 & 28.22 & 18.04 & 7.07 & 4.84 & 2.14 & 1.53 & 0.59 \\
\hline $1989-90$ & 26.51 & 16.61 & 5.93 & 3.90 & 1.53 & 1.12 & 0.39 \\
\hline 1990-91 & 26.17 & 16.28 & 5.72 & 3.74 & 1.46 & 1.08 & 0.38 \\
\hline 1991-92 & 26.91 & 16.73 & 5.85 & 3.82 & 1.50 & 1.10 & 0.39 \\
\hline 1992-93 & 27.12 & 16.94 & 5.98 & 3.91 & 1.56 & 1.13 & 0.38 \\
\hline 1993-94 & 27.40 & 17.23 & 6.21 & 4.08 & 1.70 & 1.17 & 0.40 \\
\hline 1994-95 & 27.68 & 17.52 & 6.44 & 4.24 & 1.84 & 1.22 & 0.42 \\
\hline $1995-96$ & 27.18 & 17.28 & 6.35 & 4.19 & 1.87 & 1.22 & 0.45 \\
\hline 1996-97 & 27.11 & 17.30 & 6.41 & 4.27 & 1.68 & 1.15 & 0.44 \\
\hline 1997-98 & 28.04 & 18.06 & 6.86 & 4.63 & 1.87 & 1.29 & 0.52 \\
\hline 1998-99 & 28.16 & 18.20 & 7.02 & 4.80 & 2.00 & 1.39 & 0.59 \\
\hline 1999-00 & 29.09 & 19.11 & 7.81 & 5.50 & 2.49 & 1.74 & - \\
\hline 2000-01 & 29.40 & 19.48 & 8.12 & 5.74 & 2.65 & 1.88 & - \\
\hline 2001-02 & 28.61 & 18.83 & 7.58 & 5.23 & 2.25 & 1.54 & - \\
\hline 2002-03 & 29.20 & 19.31 & 7.91 & 5.46 & 2.35 & 1.61 & - \\
\hline 2003-04 & 28.72 & 19.11 & 8.01 & 5.56 & 2.45 & 1.70 & - \\
\hline 2004-05 & 29.22 & 19.55 & 8.38 & 5.90 & 2.67 & 1.90 & - \\
\hline 2005-06 & 30.09 & 20.26 & 8.71 & 6.18 & 2.84 & 2.04 & - \\
\hline 2006-07 & 30.48 & 20.81 & 9.29 & 6.77 & 3.29 & 2.39 & - \\
\hline 2007-08 & 29.88 & 20.32 & 9.01 & 6.56 & 3.20 & 2.35 & - \\
\hline 2008-09 & 28.60 & 19.18 & 8.06 & 5.71 & 2.63 & 1.91 & - \\
\hline 2009-10 & 29.67 & 19.95 & 8.34 & 5.88 & 2.64 & 1.88 & - \\
\hline 2010-11 & 29.78 & 20.12 & 8.50 & 6.04 & 2.81 & 2.03 & - \\
\hline
\end{tabular}

Source: Authors' calculations. 
Appendix Table A4: Top income shares using updated data and tax tables and excluding dividend imputation credits and net capital gains (\%)

\begin{tabular}{|c|c|c|c|c|c|c|c|}
\hline Year & Top 10\% & Top 5\% & Top 1\% & Top $0.5 \%$ & Top $0.1 \%$ & Top $0.05 \%$ & Top $0.01 \%$ \\
\hline 1970-71 & 26.29 & 16.45 & 5.62 & 3.55 & 1.20 & 0.75 & 0.26 \\
\hline 1971-72 & 26.84 & 16.73 & 5.64 & 3.53 & 1.19 & 0.75 & 0.26 \\
\hline 1972-73 & 26.50 & 16.67 & 5.77 & 3.62 & 1.22 & 0.76 & 0.26 \\
\hline 1973-74 & 25.67 & 16.05 & 5.42 & 3.38 & 1.11 & 0.69 & 0.23 \\
\hline 1974-75 & 24.91 & 15.28 & 5.02 & 3.12 & 1.02 & 0.62 & 0.20 \\
\hline 1975-76 & 24.60 & 15.07 & 4.94 & 3.09 & 1.05 & 0.65 & 0.22 \\
\hline 1976-77 & 24.30 & 14.80 & 4.80 & 2.99 & 1.01 & 0.62 & 0.20 \\
\hline 1977-78 & 24.30 & 14.73 & 4.75 & 2.97 & 1.02 & 0.65 & - \\
\hline 1978-79 & 24.16 & 14.62 & 4.70 & 2.92 & 0.99 & 0.63 & - \\
\hline 1979-80 & 24.28 & 14.65 & 4.64 & 2.85 & 0.97 & 0.62 & - \\
\hline 1980-81 & 24.52 & 14.77 & 4.61 & 2.83 & 0.97 & 0.63 & - \\
\hline 1981-82 & 24.52 & 14.68 & 4.47 & 2.73 & 0.93 & 0.60 & - \\
\hline 1982-83 & 25.14 & 15.03 & 4.54 & 2.79 & 0.97 & 0.61 & - \\
\hline 1983-84 & 24.63 & 14.74 & 4.55 & 2.81 & 0.99 & 0.63 & - \\
\hline 1984-85 & 24.70 & 14.77 & 4.60 & 2.86 & 0.99 & - & - \\
\hline 1985-86 & 25.22 & 15.19 & 4.87 & 3.09 & 1.10 & 0.72 & 0.34 \\
\hline 1986-87 & 25.83 & 15.66 & 5.17 & 3.31 & 1.20 & 0.79 & 0.34 \\
\hline 1987-88 & 27.27 & 16.88 & 6.01 & 4.03 & 1.56 & 1.13 & 0.45 \\
\hline 1988-89 & 27.96 & 17.81 & 6.93 & 4.74 & 2.08 & 1.51 & 0.58 \\
\hline 1989-90 & 26.30 & 16.44 & 5.82 & 3.81 & 1.48 & 1.09 & 0.38 \\
\hline 1990-91 & 26.01 & 16.15 & 5.64 & 3.68 & 1.42 & 1.05 & 0.36 \\
\hline 1991-92 & 26.73 & 16.59 & 5.77 & 3.76 & 1.46 & 1.08 & 0.38 \\
\hline $1992-93$ & 26.91 & 16.77 & 5.88 & 3.84 & 1.50 & 1.09 & 0.36 \\
\hline 1993-94 & 27.14 & 17.01 & 6.09 & 3.97 & 1.63 & 1.14 & 0.38 \\
\hline 1994-95 & 27.38 & 17.25 & 6.31 & 4.11 & 1.76 & 1.19 & 0.40 \\
\hline 1995-96 & 26.79 & 16.93 & 6.14 & 3.99 & 1.75 & 1.15 & 0.39 \\
\hline 1996-97 & 26.60 & 16.85 & 6.14 & 4.03 & 1.54 & 1.05 & 0.39 \\
\hline 1997-98 & 27.31 & 17.43 & 6.44 & 4.29 & 1.66 & 1.15 & 0.43 \\
\hline 1998-99 & 27.36 & 17.53 & 6.54 & 4.40 & 1.74 & 1.21 & 0.47 \\
\hline 1999-00 & 28.22 & 18.37 & 7.22 & 5.02 & 2.13 & 1.43 & - \\
\hline 2000-01 & 28.53 & 18.71 & 7.50 & 5.22 & 2.25 & 1.51 & - \\
\hline 2001-02 & 27.77 & 18.09 & 7.05 & 4.81 & 1.96 & 1.28 & - \\
\hline 2002-03 & 28.30 & 18.54 & 7.36 & 5.04 & 2.08 & 1.36 & - \\
\hline 2003-04 & 27.43 & 18.02 & 7.25 & 4.95 & 2.05 & 1.32 & - \\
\hline 2004-05 & 27.77 & 18.30 & 7.52 & 5.11 & 2.13 & 1.41 & - \\
\hline 2005-06 & 28.33 & 18.70 & 7.59 & 5.23 & 2.15 & 1.44 & - \\
\hline 2006-07 & 27.95 & 18.60 & 7.73 & 5.45 & 2.35 & 1.65 & - \\
\hline 2007-08 & 27.82 & 18.49 & 7.69 & 5.38 & 2.31 & 1.61 & - \\
\hline 2008-09 & 27.71 & 18.39 & 7.50 & 5.23 & 2.26 & 1.59 & - \\
\hline 2009-10 & 28.73 & 19.11 & 7.77 & 5.40 & 2.30 & 1.61 & - \\
\hline 2010-11 & 28.80 & 19.23 & 7.85 & 5.47 & 2.38 & 1.66 & - \\
\hline
\end{tabular}

Source: Authors' calculations. 
Appendix Table A4.1: Increase in top income shares from including imputation credits and taxable realized capital gains (\%)

\begin{tabular}{|c|c|c|c|c|c|c|}
\hline Year & Top 10-5\% & Top 5-1\% & Top 1\% & Top $1-0.5 \%$ & Top $0.5-0.1 \%$ & Top $0.1 \%$ \\
\hline $1985-86$ & 0.00 & 0.10 & 0.21 & 0.00 & 0.00 & 0.91 \\
\hline $1986-87$ & 0.20 & 0.29 & 1.93 & 0.54 & 1.42 & 5.00 \\
\hline 1987-88 & 0.67 & 1.20 & 8.15 & 5.56 & 3.63 & 17.95 \\
\hline 1988-89 & 0.79 & 2.94 & 18.90 & 6.39 & 12.41 & 40.87 \\
\hline $1989-90$ & 0.91 & 1.41 & 7.04 & 3.98 & 5.15 & 14.19 \\
\hline $1990-91$ & 0.81 & 1.33 & 6.91 & 3.57 & 4.42 & 15.49 \\
\hline 1991-92 & 0.69 & 1.29 & 6.24 & 2.99 & 4.35 & 13.70 \\
\hline $1992-93$ & 0.89 & 1.47 & 6.63 & 3.43 & 4.29 & 15.33 \\
\hline $1993-94$ & 0.89 & 2.20 & 7.88 & 1.89 & 6.84 & 17.18 \\
\hline 1994-95 & 0.89 & 2.83 & 9.03 & 0.91 & 9.36 & 18.75 \\
\hline $1995-96$ & 0.81 & 3.24 & 10.75 & 1.86 & 12.05 & 20.00 \\
\hline $1996-97$ & 1.23 & 3.36 & 10.91 & 4.29 & 9.64 & 22.73 \\
\hline $1997-98$ & 1.82 & 3.55 & 13.51 & 7.44 & 10.27 & 26.51 \\
\hline 1998-99 & 2.24 & 3.18 & 14.53 & 8.92 & 10.15 & 28.74 \\
\hline 1999-00 & 2.34 & 2.78 & 16.34 & 9.95 & 9.34 & 31.46 \\
\hline 2000-01 & 2.04 & 3.30 & 16.40 & 9.17 & 10.14 & 31.56 \\
\hline 2001-02 & 1.96 & 3.17 & 12.48 & 9.38 & 8.42 & 22.45 \\
\hline 2002-03 & 2.25 & 3.49 & 13.18 & 9.48 & 9.80 & 22.12 \\
\hline 2003-04 & 3.08 & 4.92 & 16.69 & 9.13 & 13.45 & 29.76 \\
\hline 2004-05 & 3.48 & 5.84 & 17.95 & 4.98 & 14.05 & 37.56 \\
\hline 2005-06 & 3.32 & 6.12 & 22.00 & 11.86 & 14.29 & 44.19 \\
\hline 2006-07 & 5.35 & 8.83 & 28.72 & 14.91 & 18.97 & 54.47 \\
\hline 2007-08 & 3.86 & 7.41 & 25.36 & 10.00 & 16.61 & 52.81 \\
\hline 2008-09 & 2.47 & 4.50 & 15.73 & 8.37 & 10.44 & 30.53 \\
\hline $2009-10$ & 2.08 & 4.76 & 14.80 & 8.47 & 10.32 & 28.26 \\
\hline 2010-11 & 1.88 & 4.75 & 15.92 & 6.72 & 11.00 & 31.51 \\
\hline
\end{tabular}


Appendix Table A4.2: Top income shares using updated data and tax tables and excluding dividend imputation credits and net capital gains (\%)

\begin{tabular}{|c|c|c|c|c|c|c|}
\hline Year & Top $10-5 \%$ & Top 5-1\% & Top 1\% & Top $1-0.5 \%$ & Top $0.5-0.1 \%$ & Top $0.1 \%$ \\
\hline $1970-71$ & 9.84 & 10.82 & 5.62 & 2.07 & 2.35 & 1.20 \\
\hline $1971-72$ & 10.12 & 11.08 & 5.64 & 2.11 & 2.34 & 1.19 \\
\hline $1972-73$ & 9.82 & 10.91 & 5.77 & 2.14 & 2.41 & 1.22 \\
\hline $1973-74$ & 9.62 & 10.63 & 5.42 & 2.04 & 2.27 & 1.11 \\
\hline $1974-75$ & 9.63 & 10.26 & 5.02 & 1.90 & 2.10 & 1.02 \\
\hline $1975-76$ & 9.53 & 10.13 & 4.94 & 1.85 & 2.04 & 1.05 \\
\hline $1976-77$ & 9.50 & 10.00 & 4.80 & 1.81 & 1.99 & 1.01 \\
\hline $1977-78$ & 9.57 & 9.98 & 4.75 & 1.78 & 1.95 & 1.02 \\
\hline 1978-79 & 9.54 & 9.92 & 4.70 & 1.78 & 1.93 & 0.99 \\
\hline $1979-80$ & 9.63 & 10.01 & 4.64 & 1.79 & 1.88 & 0.97 \\
\hline 1980-81 & 9.74 & 10.16 & 4.61 & 1.78 & 1.86 & 0.97 \\
\hline $1981-82$ & 9.85 & 10.21 & 4.47 & 1.73 & 1.80 & 0.93 \\
\hline $1982-83$ & 10.11 & 10.48 & 4.54 & 1.75 & 1.82 & 0.97 \\
\hline $1983-84$ & 9.88 & 10.20 & 4.55 & 1.74 & 1.82 & 0.99 \\
\hline $1984-85$ & 9.93 & 10.17 & 4.60 & 1.74 & 1.87 & 0.99 \\
\hline $1985-86$ & 10.03 & 10.32 & 4.87 & 1.78 & 1.99 & 1.10 \\
\hline $1986-87$ & 10.17 & 10.49 & 5.17 & 1.86 & 2.11 & 1.20 \\
\hline $1987-88$ & 10.38 & 10.87 & 6.01 & 1.98 & 2.48 & 1.56 \\
\hline 1988-89 & 10.15 & 10.88 & 6.93 & 2.19 & 2.66 & 2.08 \\
\hline 1989-90 & 9.86 & 10.62 & 5.82 & 2.01 & 2.33 & 1.48 \\
\hline $1990-91$ & 9.86 & 10.51 & 5.64 & 1.96 & 2.26 & 1.42 \\
\hline $1991-92$ & 10.15 & 10.82 & 5.77 & 2.01 & 2.30 & 1.46 \\
\hline $1992-93$ & 10.14 & 10.89 & 5.88 & 2.04 & 2.33 & 1.50 \\
\hline $1993-94$ & 10.13 & 10.92 & 6.09 & 2.12 & 2.34 & 1.63 \\
\hline 1994-95 & 10.13 & 10.95 & 6.31 & 2.20 & 2.35 & 1.76 \\
\hline $1995-96$ & 9.86 & 10.79 & 6.14 & 2.15 & 2.24 & 1.75 \\
\hline 1996-97 & 9.75 & 10.71 & 6.14 & 2.10 & 2.49 & 1.54 \\
\hline $1997-98$ & 9.88 & 10.99 & 6.44 & 2.15 & 2.63 & 1.66 \\
\hline 1998-99 & 9.83 & 10.99 & 6.54 & 2.13 & 2.66 & 1.74 \\
\hline 1999-00 & 9.85 & 11.15 & 7.22 & 2.21 & 2.89 & 2.13 \\
\hline 2000-01 & 9.82 & 11.21 & 7.50 & 2.29 & 2.96 & 2.25 \\
\hline 2001-02 & 9.67 & 11.04 & 7.05 & 2.24 & 2.85 & 1.96 \\
\hline 2002-03 & 9.76 & 11.18 & 7.36 & 2.32 & 2.96 & 2.08 \\
\hline 2003-04 & 9.42 & 10.77 & 7.25 & 2.30 & 2.90 & 2.05 \\
\hline 2004-05 & 9.47 & 10.78 & 7.52 & 2.41 & 2.99 & 2.13 \\
\hline 2005-06 & 9.63 & 11.11 & 7.59 & 2.36 & 3.08 & 2.15 \\
\hline 2006-07 & 9.34 & 10.87 & 7.73 & 2.28 & 3.11 & 2.35 \\
\hline 2007-08 & 9.33 & 10.80 & 7.69 & 2.30 & 3.07 & 2.31 \\
\hline 2008-09 & 9.31 & 10.89 & 7.50 & 2.27 & 2.97 & 2.26 \\
\hline 2009-10 & 9.62 & 11.34 & 7.77 & 2.36 & 3.10 & 2.30 \\
\hline 2010-11 & 9.57 & 11.38 & 7.85 & 2.38 & 3.09 & 2.38 \\
\hline
\end{tabular}

Source: Authors' calculations derived from Appendix Table A4. 
Appendix Table A5: Percentage point change in top income shares as a result of excluding imputation credits and taxable capital gains (\%)

\begin{tabular}{|c|c|c|c|c|c|c|c|}
\hline Year & Top 10\% & Top 5\% & Top 1\% & Top $0.5 \%$ & Top $0.1 \%$ & Top $0.05 \%$ & Top $0.01 \%$ \\
\hline $1970-71$ & 0.00 & 0.00 & 0.00 & 0.00 & 0.00 & 0.00 & 0.00 \\
\hline $1971-72$ & 0.02 & 0.02 & 0.01 & 0.01 & 0.01 & 0.01 & 0.01 \\
\hline 1972-73 & -0.02 & -0.03 & -0.02 & -0.02 & -0.01 & -0.01 & -0.01 \\
\hline $1973-74$ & -0.04 & -0.04 & -0.03 & -0.02 & -0.01 & -0.01 & 0.00 \\
\hline $1974-75$ & -0.01 & -0.01 & -0.01 & -0.01 & 0.00 & -0.01 & -0.01 \\
\hline $1975-76$ & -0.02 & -0.02 & -0.01 & -0.01 & -0.01 & -0.01 & 0.00 \\
\hline $1976-77$ & -0.01 & -0.01 & -0.01 & -0.01 & 0.00 & 0.00 & 0.00 \\
\hline $1977-78$ & -0.01 & -0.01 & -0.01 & -0.01 & 0.00 & 0.00 & - \\
\hline $1978-79$ & -0.01 & -0.02 & -0.01 & 0.00 & 0.00 & 0.00 & - \\
\hline $1979-80$ & -0.05 & -0.04 & -0.02 & -0.02 & -0.01 & -0.01 & - \\
\hline 1980-81 & -0.03 & -0.03 & -0.02 & -0.02 & -0.01 & -0.01 & - \\
\hline 1981-82 & -0.01 & 0.00 & 0.00 & -0.01 & 0.00 & 0.00 & - \\
\hline 1982-83 & -0.01 & 0.00 & -0.01 & 0.00 & 0.00 & 0.00 & - \\
\hline $1983-84$ & -0.01 & -0.02 & -0.01 & -0.01 & 0.00 & -0.01 & - \\
\hline 1984-85 & -0.01 & -0.01 & -0.01 & -0.01 & -0.01 & - & - \\
\hline $1985-86$ & -0.02 & -0.02 & -0.01 & -0.01 & -0.01 & -0.01 & 0.00 \\
\hline $1986-87$ & -0.14 & -0.13 & -0.10 & -0.08 & -0.06 & -0.04 & -0.01 \\
\hline $1987-88$ & -0.68 & -0.62 & -0.49 & -0.38 & -0.28 & -0.25 & -0.13 \\
\hline 1988-89 & -1.71 & -1.63 & -1.31 & -1.17 & -0.85 & -0.57 & -0.38 \\
\hline 1989-90 & -0.65 & -0.56 & -0.41 & -0.33 & -0.21 & -0.13 & -0.07 \\
\hline 1990-91 & -0.60 & -0.52 & -0.39 & -0.32 & -0.22 & -0.15 & -0.09 \\
\hline 1991-92 & -0.58 & -0.49 & -0.36 & -0.30 & -0.20 & -0.13 & -0.08 \\
\hline 1992-93 & -0.64 & -0.55 & -0.39 & -0.33 & -0.23 & -0.15 & -0.10 \\
\hline 1993-94 & -0.81 & -0.72 & -0.48 & -0.44 & -0.28 & -0.17 & -0.13 \\
\hline 1994-95 & -0.98 & -0.89 & -0.57 & -0.54 & -0.33 & -0.20 & -0.16 \\
\hline 1995-96 & -1.08 & -1.00 & -0.66 & -0.62 & -0.35 & -0.24 & -0.18 \\
\hline 1996-97 & -1.15 & -1.03 & -0.67 & -0.59 & -0.35 & -0.25 & -0.14 \\
\hline $1997-98$ & -1.44 & -1.26 & -0.87 & -0.71 & -0.44 & -0.30 & -0.17 \\
\hline 1998-99 & -1.53 & -1.30 & -0.95 & -0.77 & -0.50 & -0.35 & -0.21 \\
\hline 1999-00 & -1.73 & -1.49 & -1.18 & -0.95 & -0.67 & -0.59 & - \\
\hline 2000-01 & -1.80 & -1.59 & -1.23 & -1.00 & -0.71 & -0.65 & - \\
\hline 2001-02 & -1.41 & -1.23 & -0.88 & -0.68 & -0.44 & -0.39 & - \\
\hline 2002-03 & -1.58 & -1.36 & -0.97 & -0.75 & -0.46 & -0.41 & - \\
\hline 2003-04 & -2.05 & -1.74 & -1.21 & -1.00 & -0.61 & -0.57 & - \\
\hline 2004-05 & -2.31 & -1.98 & -1.35 & -1.23 & -0.80 & -0.69 & - \\
\hline 2005-06 & -2.67 & -2.35 & -1.67 & -1.39 & -0.95 & -0.78 & - \\
\hline 2006-07 & -3.67 & -3.19 & -2.22 & -1.89 & -1.28 & -0.99 & - \\
\hline 2007-08 & -3.11 & -2.75 & -1.95 & -1.73 & -1.22 & -0.98 & - \\
\hline 2008-09 & -1.89 & -1.67 & -1.18 & -1.00 & -0.69 & -0.55 & - \\
\hline 2009-10 & -1.89 & -1.68 & -1.15 & -0.96 & -0.65 & -0.49 & - \\
\hline 2010-11 & -1.97 & -1.79 & -1.25 & -1.09 & -0.75 & -0.62 & - \\
\hline
\end{tabular}

Source: Authors' calculations. Note: Estimates are obtained by subtracting each estimate in Table A4 from the corresponding estimate in Table A2. 


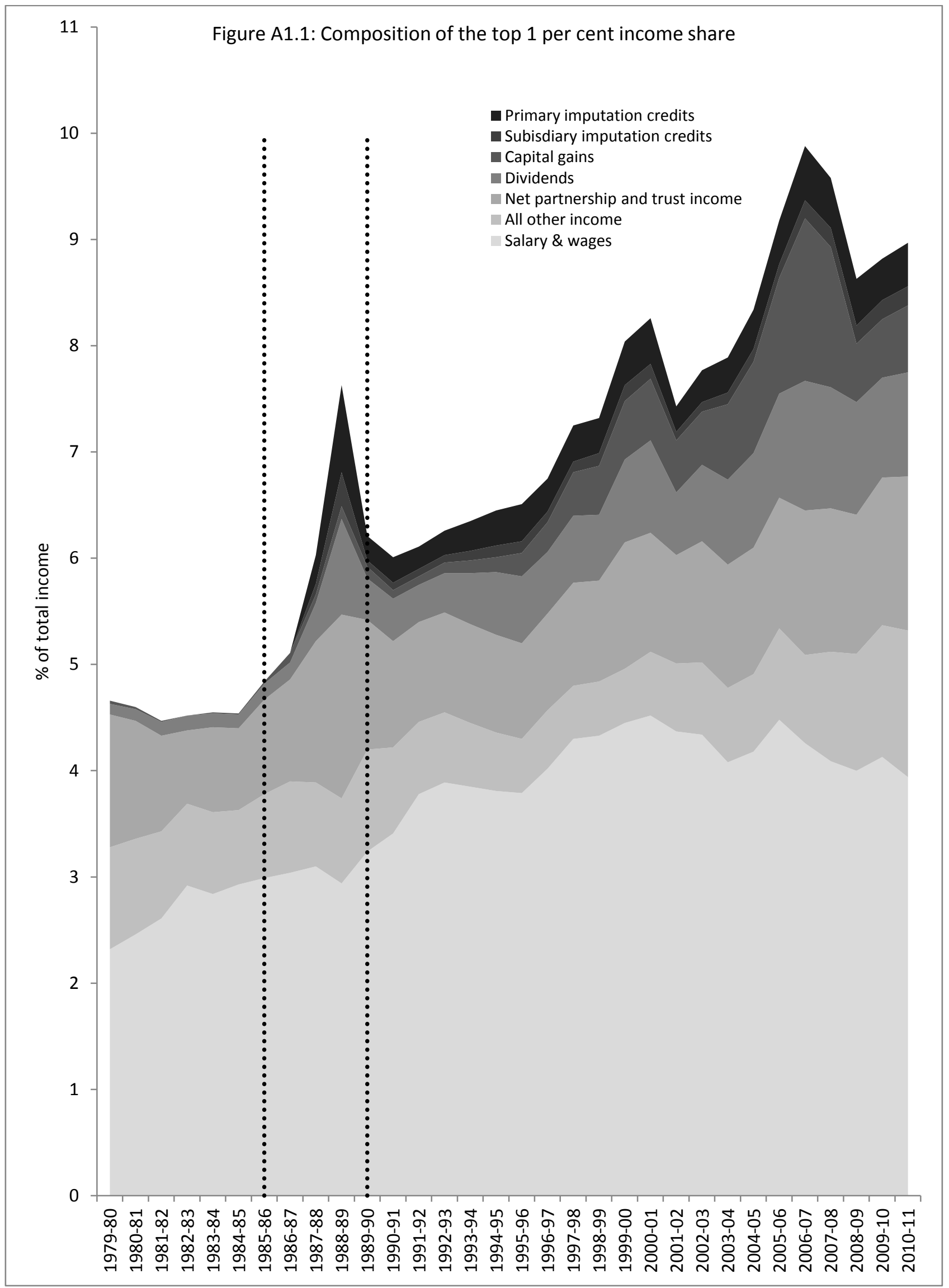

Sources: Authors' calculations. 


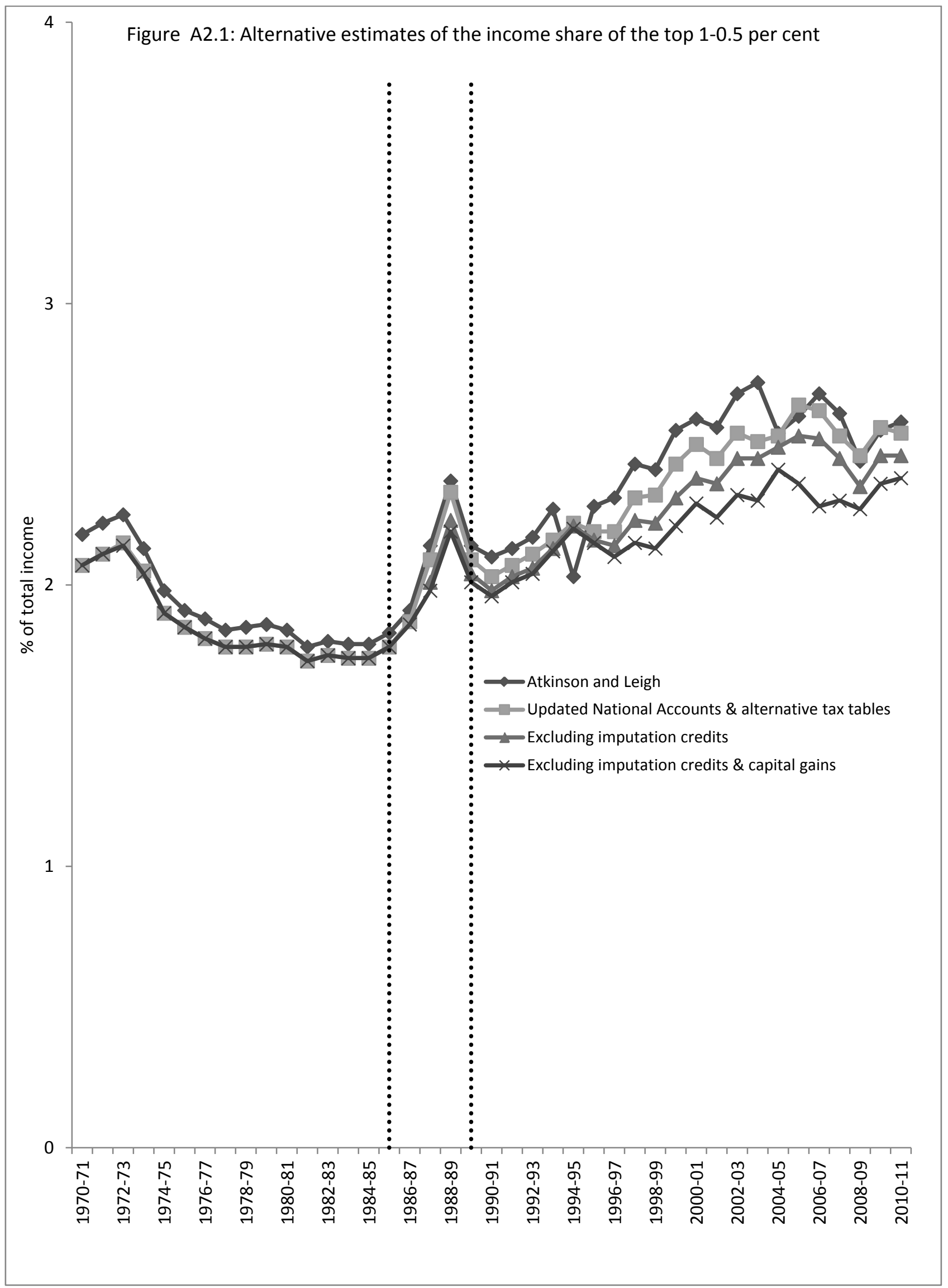

Source: Authors' calculations. 


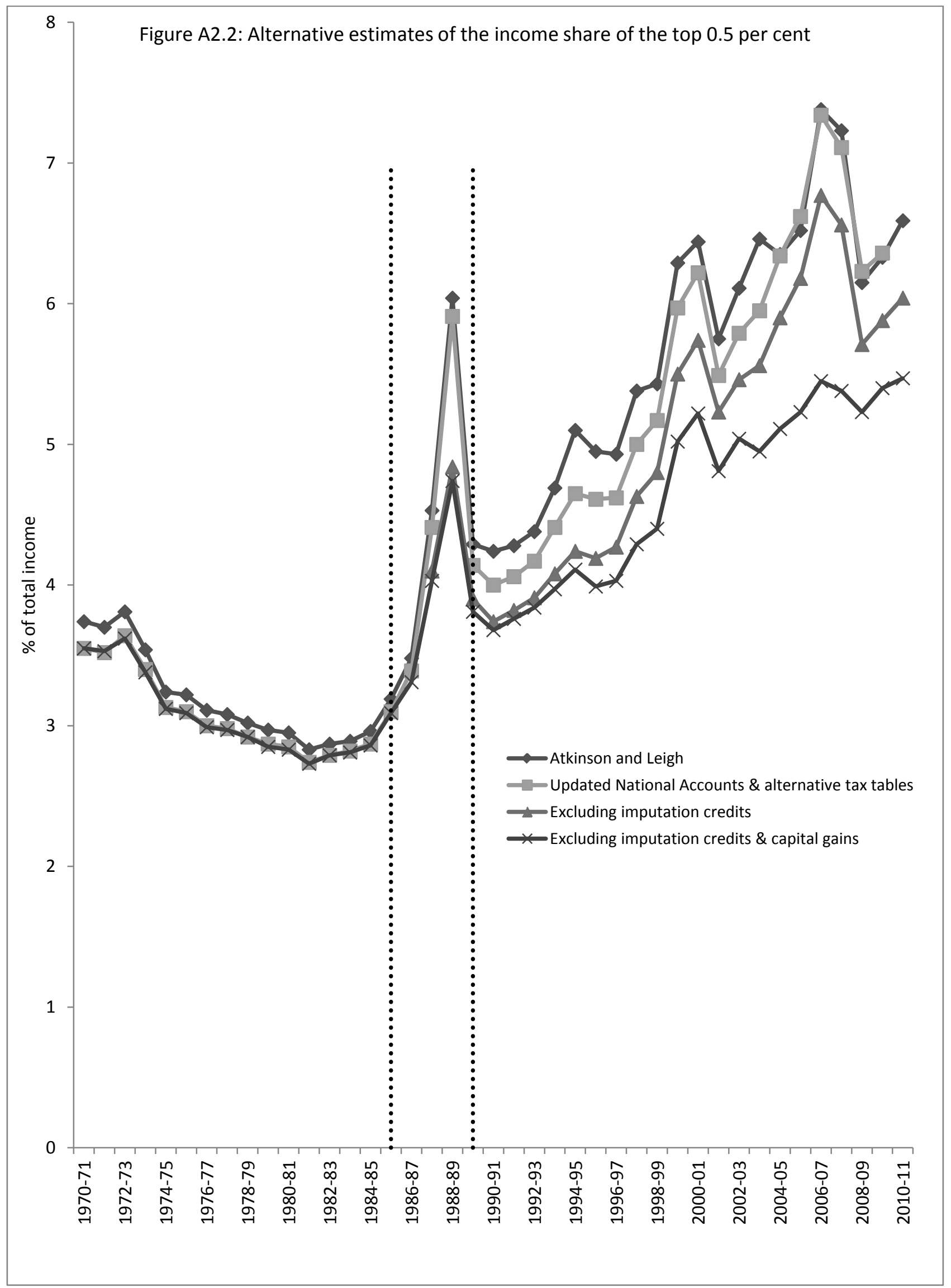

Source: Authors' calculations. 


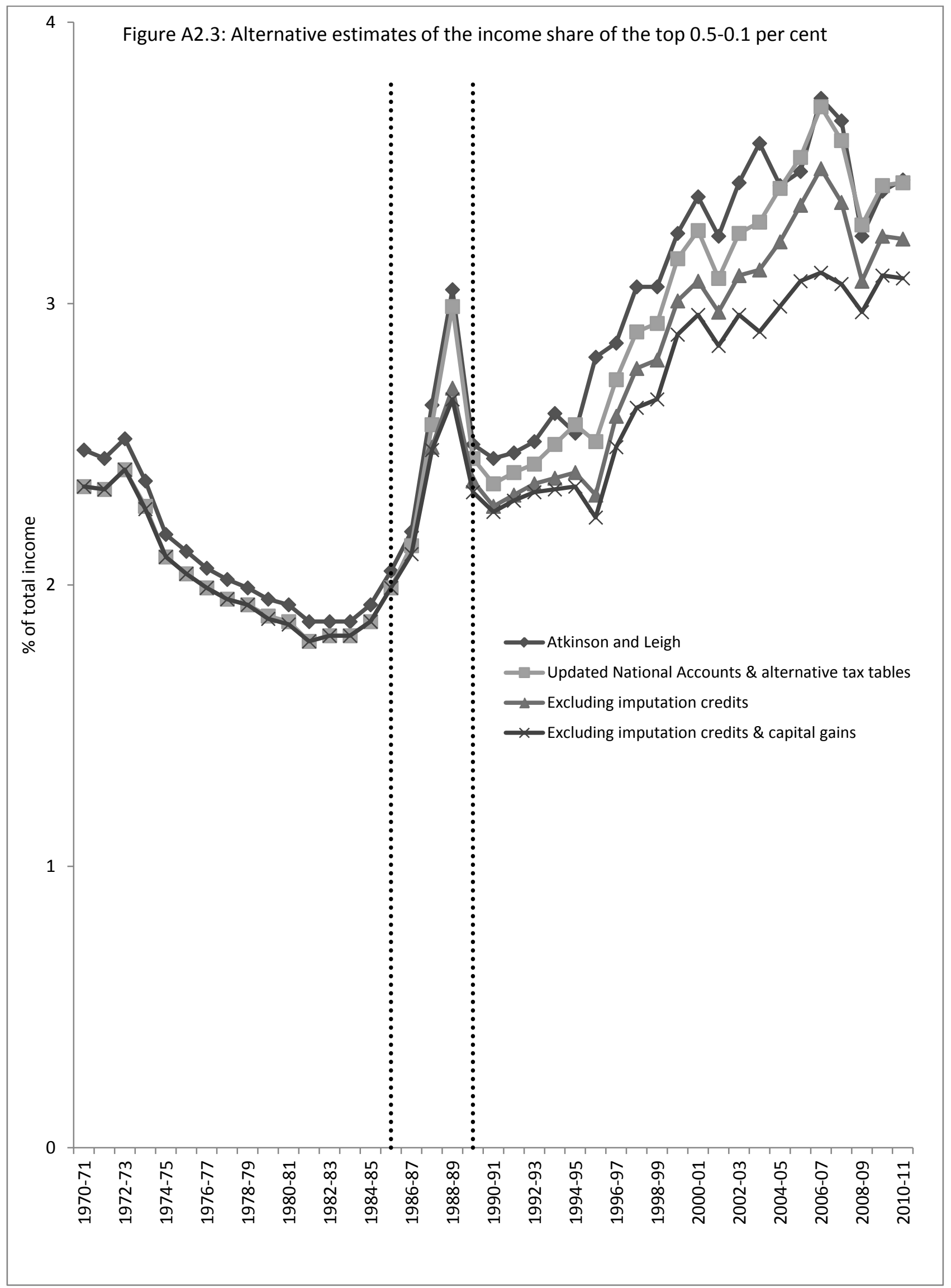

Source: Authors' calculations. 


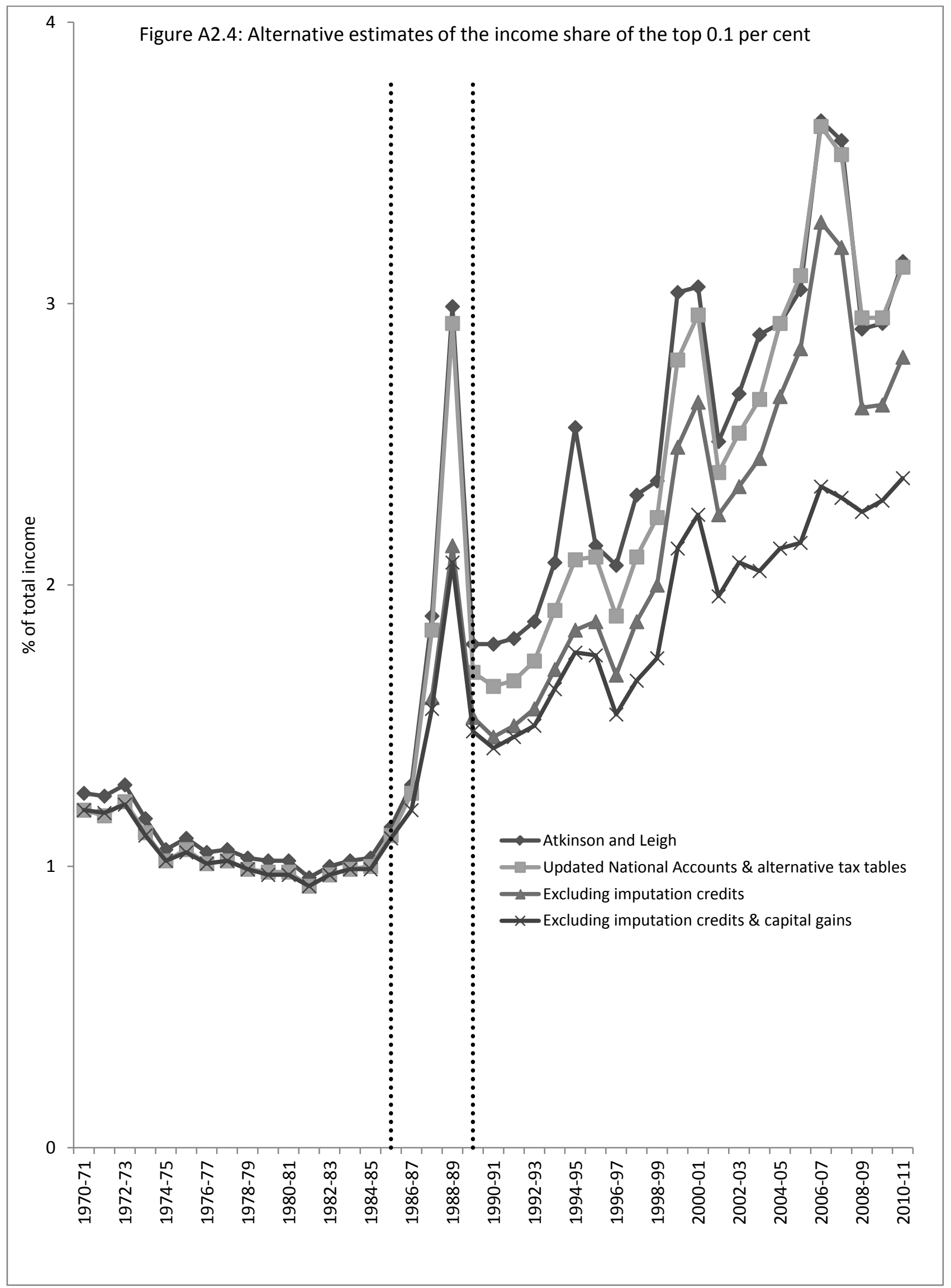

Source: Authors' calculations. 
Table A6: Alternative Table 2-Distribution of alternative measures of capital gains, 2006 and 2009-Including negative capital gains values

\begin{tabular}{|c|c|c|c|c|c|c|c|c|}
\hline & \multicolumn{2}{|c|}{ Realized taxable capital gains } & \multicolumn{2}{|c|}{ Accrued taxable capital gains } & \multicolumn{2}{|c|}{$\begin{array}{c}\text { Accrued non-taxable capital } \\
\text { gains }\end{array}$} & \multicolumn{2}{|c|}{$\begin{array}{c}\text { Accrued taxable and } \\
\text { non-taxable capital gains }\end{array}$} \\
\hline & $\$$ & $(\%)$ & $\$$ & $(\%)$ & $\$$ & $(\%)$ & $\$$ & $(\%)$ \\
\hline \multicolumn{9}{|l|}{ 2006-07 } \\
\hline \multicolumn{9}{|c|}{ Location in income distribution } \\
\hline Bottom 90\% & 1,054 & 57.7 & 6,522 & 25.8 & 11,876 & 36.3 & 22,163 & 38.2 \\
\hline Percentiles 91 to 95 & 2,336 & 6.8 & 60,806 & 13.3 & 113,683 & 19.3 & 173,443 & 16.6 \\
\hline Percentiles 96 to 99 & 5,986 & 14.5 & 171,055 & 30.1 & 196,967 & 26.8 & 344,453 & 26.4 \\
\hline Top percentile & 34,727 & 20.9 & 707,523 & 30.8 & 517,867 & 17.5 & 982,989 & 18.7 \\
\hline Total & $26,229,391,372$ & 100.0 & $362,514,535,198$ & 100.0 & $468,264,416,549$ & 100.0 & $830,778,951,202$ & 100.0 \\
\hline Mean & 1,648 & & 22,772 & & 29,415 & & 52,188 & \\
\hline Median & 1,037 & & 0 & & 6,833 & & 12,994 & \\
\hline \multicolumn{9}{|l|}{ 2009-10 } \\
\hline \multicolumn{9}{|c|}{ Location in income distribution } \\
\hline Bottom $90 \%$ & 385 & 68.3 & 889 & 21.8 & $-1,878$ & -21.3 & 89 & 0.7 \\
\hline Percentiles 91 to 95 & 545 & 5.1 & 16,812 & 22.9 & 50,156 & 31.6 & 61,907 & 26.6 \\
\hline Percentiles 96 to 99 & 1,963 & 15.4 & 29,608 & 32.2 & 103,339 & 52.1 & 125,368 & 43.3 \\
\hline Top percentile & 5,700 & 11.2 & 85,238 & 23.1 & 297,788 & 37.6 & 343,534 & 29.4 \\
\hline Total & $8,669,889,477$ & 100.0 & $62,650,186,282$ & 100.0 & $135,077,051,913$ & 100.0 & $197,727,237,587$ & 100.0 \\
\hline Mean & 509 & & 3,675 & & 7,925 & & 11,600 & \\
\hline Median & 359 & & 0 & & -14 & & 0 & \\
\hline
\end{tabular}

Notes: For incomes by location in the income distribution, individuals are ordered in each column by the income measure indicated in the column heading. Dollar amounts are in 2009-10 Australian dollars. 
Table A7: Alternative Table 3—Distribution of income using alternative measures of capital gains, 2006 and 2009 —Including negative capital gains values

\begin{tabular}{|c|c|c|c|c|c|c|c|c|c|c|}
\hline & \multicolumn{2}{|c|}{ Income without capital gains } & \multicolumn{2}{|c|}{$\begin{array}{l}\text { Income with realized taxable } \\
\text { capital gains }\end{array}$} & \multicolumn{2}{|c|}{$\begin{array}{l}\text { Income with accrued taxable } \\
\text { capital gains }\end{array}$} & \multicolumn{2}{|c|}{$\begin{array}{c}\text { Income with accrued } \\
\text { non-taxable capital gains }\end{array}$} & \multicolumn{2}{|c|}{$\begin{array}{c}\text { Income with accrued taxable } \\
\text { and non-taxable capital } \\
\text { gains }\end{array}$} \\
\hline & $\$$ & $(\%)$ & $\$$ & $(\%)$ & $\$$ & $(\%)$ & $\$$ & $(\%)$ & $\$$ & $(\%)$ \\
\hline \multicolumn{11}{|l|}{ 2006-07 } \\
\hline \multicolumn{11}{|c|}{ Location in income distribution } \\
\hline Bottom $90 \%$ & 29,170 & 63.7 & 30,225 & 63.5 & 38,078 & 53.5 & 43,995 & 56.0 & 54,948 & 52.9 \\
\hline Percentiles 91 to 95 & 97,515 & 11.3 & 99,851 & 11.1 & 155,854 & 12.1 & 199,891 & 14.1 & 259,085 & 13.9 \\
\hline Percentiles 96 to 99 & 147,899 & 14.3 & 153,884 & 14.3 & 299,539 & 18.7 & 320,957 & 18.2 & 459,103 & 19.7 \\
\hline Top percentile & 441,509 & 10.6 & 476,236 & 11.0 & $1,009,953$ & 15.7 & 829,959 & 11.7 & $1,275,568$ & 13.6 \\
\hline Total & $657,294,375,852$ & 100.0 & $683,523,765,745$ & 100.0 & $1,019,808,907,295$ & 100.0 & $1,125,558,787,542$ & 100.0 & $1,488,073,320,574$ & 100.0 \\
\hline Mean & 41,290 & & 42,937 & & 64,062 & & 70,705 & & 93,477 & \\
\hline Median & 29,233 & & 31,208 & & 37,211 & & 45,830 & & 52,500 & \\
\hline \multicolumn{11}{|l|}{$2009-10$} \\
\hline \multicolumn{11}{|c|}{ Location in income distribution } \\
\hline Bottom 90\% & 30,104 & 63.7 & 30,489 & 63.7 & 31,590 & 61.3 & 31,010 & 55.1 & 33,073 & 54.8 \\
\hline Percentiles 91 to 95 & 102,568 & 11.3 & 103,113 & 11.3 & 115,079 & 12.4 & 140,648 & 13.9 & 151,835 & 14.0 \\
\hline Percentiles 96 to 99 & 155,032 & 14.5 & 156,996 & 14.5 & 177,622 & 15.3 & 235,964 & 18.6 & 256,294 & 18.9 \\
\hline Top percentile & 449,227 & 10.5 & 454,927 & 10.5 & 509,726 & 11.0 & 625,241 & 12.4 & 673,798 & 12.3 \\
\hline Total & $727,831,670,558$ & 100.0 & $736,501,561,146$ & 100.0 & $790,481,856,906$ & 100.0 & $862,908,722,287$ & 100.0 & $925,558,907,738$ & 100.0 \\
\hline Mean & 42,699 & & 43,208 & & 46,375 & & 50,624 & & 54,299 & \\
\hline Median & 29,996 & & 30,644 & & 30,996 & & 35,327 & & 36,996 & \\
\hline
\end{tabular}

heading. Dollar amounts are in 2009-10 Australian dollars 


\section{Appendix: Sources and methods used to calculate top income shares using taxation data}

We calculate top income shares using taxation data by drawing on tabulations of the number of taxpayers in each of a number of income ranges or brackets. These tables permit identification of the number of taxpayers above specified thresholds and the total income they declared to the tax office. We then bring this information together with information on the total number of people in the population and estimates of the total income of the population-referred to in this literature as control totals for population and income.

We are interested in particular population thresholds (such as the top 1 per cent) that will almost certainly not coincide with the tabulated income brackets. So we need a method to impute incomes of those members of the lowest income band containing the population of interest. For example, if the 99th percentile falls in the $\$ 200,000$ to $\$ 220,000$ income band, to obtain the income share of the top 1 per cent, we require a method for imputing the incomes of the top 1 per cent members. Two methods are used in the literature: Pareto imputation and the mean-split histogram method. We use the meansplit histogram method to be consistent with the existing Australian literature.

Our methods resemble closely those in Atkinson and Leigh (2005, 2007)-henceforth AL. Throughout the Appendix, we will mention whenever our methods deviate from AL. Below we first introduce the control totals for population and income, then provide description of the taxation tables and related issues. We then describe how we exclude dividend imputation credits and capital gains from the top income share series. Finally, we provide a description of the mean-split histogram method.

Control total for population. We choose as the control population every person aged 15 years and over. We use the most recent population estimates from Australian Bureau of Statistics (ABS) published data in Australian Demographic Statistics, Sep 2012: Table 59. Estimated Resident Population By Single Year Of Age, Australia (Catalogue No. 3101.0) (ABS 2013a). This table contains 
population estimates for Australia by tax year (financial year), gender and age. The control total for the population is simply the total number of persons aged 15 and over in each year.

The population totals we use are slightly different from those used by AL, who use different releases of the population estimates, whereas we only use the most recent release, which contains population estimates for all years back to 1970. In principle, using different versions may affect the consistency of the top income shares over time. Our analysis shows, however, that this does not in practice significantly affect population totals.

Control total for income. The control total for income is calculated from various income aggregates found in the National Accounts, in particular in the household income account. The data are published by the ABS in The Australian System of National Accounts 2011-12: Table 36. Household Income Account, Current Prices (Catalogue No. 5204.0) (ABS 2012). This table contains income earned by persons living in Australia and by unincorporated businesses owned by Australian households.

The income total is defined as the sum of gross mixed income, compensation of employees, interest, dividends, workers’ compensation, and social assistance benefits, minus interest payable by unincorporated enterprises and household sector consumption of fixed capital. Table A8 provides descriptions of the main components. It is notable that most capital gains are not included in the control total for income-some capital gains of unincorporated enterprises may be included in gross mixed income, but no other capital gains are captured.

We employ the most recent release of the National Accounts data available (as at the time of writing), which was published in November 2012. This release provides the best and most consistently measured income data currently available for all years that we examine. That is, the most recent release incorporates, for all years under study, all revisions to estimates made subsequent to first release and, insofar as possible, applies consistent definitions and approaches to measurement across all years. AL, on the other hand, use various different releases after 2003, so that estimates do not take into account 
changes to definitions and measurement or revisions to estimates made subsequent to 2003 for pre2003 estimates, or changes and revisions subsequent to first release for post-2003 estimates.

\section{Taxation Statistics}

We rely on published taxation statistics. For the period from 1970 to 1994, tables published by the Australian Taxation Office (ATO) are available only in printed form. For the period from 1994 to 1999, the tax tables we use come from CD-ROMs that accompanied the printed publications, while for the period from 1999 to 2010 we download all tables from the ATO website.

During our period of interest, the relevant tables present the number of persons and total income, dividends, dividend imputation credits and taxable capital gains in each of a number of taxable income brackets. ${ }^{32}$ Table A9 provides details on the tax tables we use and the definitions of the relevant income variables in each tax year. In common with AL, in tax years 1985 to 1988, we combine two sets of tables: the "main” tables, and "supplementary” tables, which provide tabulations on persons with taxable incomes of $\$ 500,000$ and over. This increases the number of income brackets at the top of the distribution and allows for more accurate imputation of top income shares in those years. ${ }^{33}$ Note, however, that our tables are different from the main tables AL use for the years 1993-1999 because we are interested in imputation credits and net capital gains, and the tables AL use do not contain this information. However, our results show that these differences in methodology have little effect on the top income shares series, as the very small differences in estimates between Tables A1 and A1.2 show.

Table A9 shows that tabulations are by "net income” from 1970 to 1976 and by “taxable income” thereafter. However, the two variables are defined very similarly. Net income is defined as

\footnotetext{
${ }^{32}$ We will be using the ATO definitions of income throughout this Appendix. These definitions will be described in the next paragraph.

33 AL also use supplementary tables from 1989 to 1998 . We do not use these tables because they are not required for 1989 , 1990 and 1991 (the number of income brackets available in the main tables were increased), while from 1992 to 1998 , the income variable in the supplementary tables is taxable income, which is not comparable with the main tables, for which the income variable is total income.
} 
total assessable income - which comprises ordinary gross income plus income items made specifically assessable, such as dividend imputation credits (from 1987-88 onwards)—less total deductions for expenses incurred in gaining that income; taxable income is defined as total assessable income less any deductions allowed under the "Income Tax Assessment Act 1936 (or 1997).” A limited number of deductions allowable under the Act do not relate to expenses incurred in gaining income, so taxable income is slightly lower than net income. The table also shows that, after combining the main and supplementary tables for 1985 to 1988, the number of income brackets by which variables can be tabulated ranges from a low of 10 (in 1994) to a high of 32 (in 1985).

The income measure is "net income” from 1970 to 1991, "total income" from 1992 to 1999, and “total income or loss" from 2000 to 2010. Both "total income” and "total income or loss" are defined as total assessable income (i.e., income before deductions). The income measure is thus consistently defined from 1992 onwards. However, there is a significant inconsistency between the pre-1992 income measure and the income measure available from 1992. Like AL, we do not address this inconsistency. Since total income is larger than net income (and the control total for income is unaffected), this will cause a spurious increase in measured top income shares post-1991 compared with the earlier period.

Our analysis to this point is very similar to AL. However, we are interested in creating a series that excludes dividend imputation credits and capital gains.

Imputation credits. As described in Section 2, a change to dividend taxation took effect from July 1, 1987. From July 1, 1940 to June 30, 1987, dividends were taxed twice: as profits through the company tax system; and as shareholders' income through the personal income tax system. Double taxation ended from July 1, 1987 with the implementation of an imputation system whereby shareholders receive tax credits that can be used to offset their personal income tax liability. The change was announced on 19 September 1985, legislated on 10 December 1986, and took effect from 1 July 1987. 
As a result of this change, tax records from the 1987 tax year onwards include imputation or franking credits, which is equal to the amount of the company tax paid attributable to the dividends tax filers receive. Imputation credits added to dividends equal the imputed gross or pre-tax dividend income received by the tax filer. This creates an inconsistency with the pre-1987 tax records, which contain only dividends net of company tax.

We can identify imputation credits in the more detailed Australian tax tables we use. These tables contain the total value of imputation credits by taxable income ranges in all years in which the imputation system is in operation—from 1987 onward. Because we base our top income series on these more detailed tax tables we are able to subtract these credits from taxable income. From 1988, "primary" imputation credits can be distinguished from "subsidiary" imputation credits. Primary imputation credits derive from dividends on shares directly owned by the tax filer, while subsidiary imputation credits are those received indirectly as part of a distribution from a trust or partnership that owns shares attracting imputation credits. For 1987, to disaggregate total imputation credits into its primary and subsidiary components, we assume the 1988 ratio of primary to subsidiary credits applies.

Capital gains. As we explain in Section 2, prior to 1972, capital gains were essentially untaxed, although the 1936 Tax Act did make provision for capital gains taxation, and some capital gains did appear in the tax tables from 1969 to 1971 as "profit (or loss) from sale of real estate, shares, etc.” (as Table A9 shows for 1970 and 1971). However, the value of this item was very small, and the conditions under which capital gains were deemed taxable are unclear. From 1972, all capital gains on certain assets held less than one year were explicitly made taxable, and all assets held for at least one year were explicitly made non-taxable. As Table A9 shows, these capital gains continued to appear in the tax records data as “profit (or loss) from sale of real estate, shares, etc.” until 1984. They appeared as "sale of property" in 1985 and as "sale of property” plus “net capital gains” in 1986. For the period from 1970 to 1978 , only the total value of this income component is available-that is, it is not 
tabulated by taxable income bracket. We therefore imputed it for each income bracket by assuming the same distribution across income brackets as observed in $1979 .{ }^{34}$

Tax law changes proposed on 19 September 1985, passed into legislation on 10 December 1986, and effective 1 July 1987 resulted in realized capital gains on assets acquired after 19 September 1985 being taxed comprehensively, with exceptions made for gains from the selling of the principal residence and gains from superannuation (private pensions) and life insurance. Capital losses can be used to reduce capital gains until they fully offset total capital gains in a given year. Net capital losses cannot be used to reduce tax liability of other income sources but will carry forward and reduce tax liability on capital gains in future years. The stock of net capital losses carries forward until exhausted.

Until 1999, only real capital gains were taxed (indexation method). Net capital gains were calculated as total capital gains less capital losses (total capital losses of the current year and net capital losses from previous years). A change in tax law in 1999 meant that capital gains of assets acquired after 20 September 1999 were taxed in nominal rather than real terms, but with a discount of 50 per cent applied to assets held more than 12 months (discount method). For assets acquired before 20 September 1999, taxpayers could (and can still) choose to use either the indexation or the discount method. If the discount method is applied, net capital gains are calculated as total (nominal) capital gains less capital losses (total capital losses of the current year and net capital losses from previous years) with a 50 per cent discount for assets held more than 12 months.

Since the taxation tables that AL use do not include information on imputation credits or capital gains, we use alternative tables which contain capital gains information. Table A9 shows that tabulations of net capital gains by ranges of taxable income are available from 1986. Note that in 1986 and 1987, net capital gains are available only for a limited number of income brackets. We impute

\footnotetext{
${ }^{34}$ The number of income brackets differs across the 1970 to 1979 tax years, requiring some brackets to be collapsed and others to be split to match the 1979 brackets. However, differences in income brackets are for the most part restricted to the lower income brackets, so this had little effect on estimates of capital gains relevant to top income groups.
} 
them by assuming the same distribution across income brackets as in 1985 (for 1986) and 1988 (for 1987). In practice, this has no significance because the net capital gains recorded in the tax data relate only to assets acquired after 19 September 1985 (if held more than one year), which were close to negligible in 1986 and 1987.

Removing imputation credits and capital gains from the top incomes shares series. With the more detailed tax tables, we create a series beginning in 1986 that excludes imputation credits and net capital gains. To do this, we simply subtract imputation credits and net capital gains from the income measure (net income from 1986 to 1991; total income from 1992 to 2010) in each income bracket before calculating the top income shares.

We implicitly assume that imputation credits and capital gains within an income bracket are the same proportion of total income for all individuals within the bracket. That is, we assume no change to the ranking of individuals after removal of imputation credits and capital gains. This is because the income brackets are defined in terms of income including imputation credits and capital gains, and are fixed—we simply subtract total imputation credits and capital gains of individuals in that bracket from the total income of individuals in that bracket to obtain our revised income total. It is, however, likely that imputation credits and capital gains within each income bracket are not distributed in this manner. For example, if the means of imputation credits and capital gains within an income bracket arise from a few individuals with large values (with most individuals having little or no imputation credits or capital gains), then excluding imputation credits and capital gains will result in those individuals moving down the income distribution relative to other individuals. This would mean that some individuals in our top $x$ per cent should not actually be in our top $x$ per cent—and some individuals in lower income brackets (inclusive of imputation credits and capital gains) who are not in our top $x$ per cent should be in our top $x$ per cent. This will cause us to underestimate the total income of the top $x$ per cent, implying our estimates will understate the true income share of the top $x$ per cent. 
It is not possible to ascertain the extent of understatement (if any) of top income shares from the published tax tables themselves. However, as of the time of the writing of this paper, the ATO has released one per cent samples of unit record tax data for each tax year from 2003 to 2009. The samples contain individual-level tax record data for a limited number of income and tax components, including capital gains income and "franked" dividend income. While the sample files are inferior to the tax tables for calculating top income shares, both because of the limited sample sizes and because of topcoding of data items, their unit-record structure allows us to gauge the impact of re-ranking. Specifically, we can replicate the tax table analysis for the unit-record data-that is, create tax tables analogous to those used in the analysis reported in the main body of this paper, and estimate top income shares from these tables_-but do this in two alternative ways:

(1) Replicate our approach to removing capital gains and imputation credits using the ATO tax tables (as described below in this Appendix).

(2) Create tax tables by ranges of an income variable that excludes capital gains and imputation credits, which we obtain by subtracting capital gains and imputation credits from the total taxable income of each individual prior to creating the tables.

The second approach produces "correct” estimates of top income shares, although the estimates will in fact contain errors due to imputation within income ranges (as described below in this Appendix). This is deliberate, so as to allow isolation of the effect of the re-ranking that occurs due to exclusion of capital gains and imputation credits. The difference between the "correct" estimate and the “replicated” estimate therefore provides a measure of the error due to re-ranking.

The sample files do not actually contain information on imputation credits. Rather, we have the value of "franked" dividends for each tax filer in the sample. This permits identification of the value of “primary” imputation credits, but not "subsidiary” imputation credits. Primary imputation credits are equal to the company tax payable on the profits from which dividends are paid. Over the 2003 to 2009 
period, the company tax rate was 30 per cent, implying primary imputation credits are equal to 30 per cent of the grossed-up value of franked dividends-which translates to 42.9 per cent of franked dividends as reported in the taxation statistics (since franked dividends equal 70 per cent of grossed-up dividends). However, subsidiary imputation credits relate to distributions from public trusts and partnerships, which are not separately recorded in the sample files. We make the assumption that, within each range of taxable income, subsidiary imputation credits are distributed across individuals in the same manner as primary imputation credits. In practice, this means that imputation credits of each individual are multiplied by a factor equal to one plus the ratio of subsidiary imputation credits to primary imputation credits in that individual's income range. The total value of subsidiary imputation credits is approximately 30 per cent of the total value of primary imputation credits. On average this factor is approximately 1.3.

Table A10 presents the results of this exercise for top 1 per cent income shares. It shows that not accounting for re-ranking results in a top 1 per cent income share between 0.16 and 0.26 percentage points lower than its true level. It is therefore clear that the approach we take leads to slight underestimation of the income share of the top 1 per cent. However, the table also shows that this error is substantially smaller in magnitude than the error (relative to a consistently measured top income share) in a series that fails to exclude imputation credits and capital gains. Compared with a consistently measured series, including imputation credits and capital gains will result in an overestimation of the income share of the top 1 per cent of between 0.54 and 2.21 percentage points. The extent of overestimation is especially large in 2006 and 2007, when capital gains incomes were at their highest over the 2003 to 2009 period. 


\section{Mean-split histogram method}

The following description for the mean-split histogram imputation method draws upon Atkinson (2005). The formula is:

$$
\Omega=G(y(H)) / \mu=\left\{\begin{array}{c}
\Omega_{i}-\left[\left(H_{i}-H\right) y_{i}+\frac{1}{2} \frac{\left(H_{i}-H\right)^{2}}{\left.\left(\frac{\left(H_{i}-H_{i}^{M S H}\right)}{\left(\mu_{i}-y_{i}\right)}\right)\right]} \text { if } H_{i}>H>H_{i}^{M S H}\right. \\
\Omega_{i+1}+\left[\left(H-H_{i+1}\right) y_{i+1}-\frac{1}{2} \frac{\left(H-H_{i+1}\right)^{2}}{\left(\frac{\left(H_{i}^{M S H}-H_{i+1}\right)}{\left(y_{i+1}-\mu_{i}\right)}\right)}\right] \text { if } H_{i}^{M S H} \geq H \geq H_{i+1}
\end{array}\right.
$$

Where:

$$
H_{i}^{M S H}=\frac{H_{i}\left(\mu_{i}-y_{i}\right)+H_{i+1}\left(y_{i+1}-\mu_{i}\right)}{\left(y_{i+1}-y_{i}\right)}
$$

$y_{i}$ and $y_{i+1}$ are the relative lower and upper bound of the income bracket $i$ (relative to and thus divided by the overall mean income $\mu$ ); $\mu_{i}$ is the relative mean of income bracket $i ; H_{i}$ and $H_{i+1}$ are the percentages of people with respective incomes equal to or above $y_{i}$ and $y_{i+1}\left(H_{i}\right.$ and $H_{i+1}$ thus indicate the top $H_{i} \%$ and $H_{i+1} \%$ of the income distribution); $\Omega_{i}$ and $\Omega_{i+1}$ are the respective income shares of the top $H_{i} \%$ and $H_{i+1} \%$.

We are interested in calculating $\Omega=G(y(H)) / \mu$, which is the share of income held by the top $H \%$ of the income distribution. $H$ is often set to $10 \%, 5 \%$ or $1 \%$. The procedure is as follows:

1. For each income bracket $i$ (of a taxation table such as table A11), calculate the mean income, percentage of persons and percentage of income held using the control totals for population and income. 
2. For each income bracket $i$, calculate the cumulative percentage of persons $\left(H_{i}\right)$ and percentage of income held $\left(\Omega_{i}\right)$ by adding up the percentages calculated in 1) from the last income bracket to the first income bracket.

3. Choose $H$ (top $H \%$ of income distribution).

4. Find the income bracket $i$ for which $H_{i}>H \geq H_{i+1}$.

5. For the chosen income bracket $i$, calculate the relative lower bound $\left(y_{i}\right)$, relative upper bound $\left(y_{i+1}\right)$ and relative mean income $\left(\mu_{i}\right)$ by dividing the (absolute) values given in the taxation table by the overall mean income $\mu$.

6. Calculate $H_{i}^{M S H}$.

7. Calculate $\Omega=G(y(H))$.

As an example, suppose we want to calculate the income share held by the top 1 per cent for the tax year 2009. We are therefore using information from the 2009 Taxation Statistics (see Table A11). For this exercise, the income measure we are interested in is "Total income minus imputation credits and capital gains.” The results of steps 1 and 2 are listed in the right section of Table A11.

Since we have chosen $H=1$, we will impute from income bracket $i=19$. For this income bracket, $\mathrm{H}$ lies between $H_{19}=1.18$ and $H_{20}=0.57$. This income bracket has a lower bound of $\$ 180,001$ and an upper bound of $\$ 250,000$. The mean income is $\$ 201,533$. These values relative to the overall mean income $(\mu=45,834)$ are: $y_{19}=3.93$ (relative lower bound); $y_{20}=5.45$ (relative upper bound); and $\mu_{19}=4.40$ (relative mean income). Using the formula for $H_{i}^{M S H}$ we get:

$$
H_{19}^{M S H}=\frac{1.18(4.40-3.93)+0.57(5.45-4.40)}{(5.45-3.93)}=0.75
$$

Since $H=1$ lies between $H_{19}=1.18$ and $H_{19}^{M S H}=0.75$, we will use the top branch of the formula for $\Omega=G(y(H))$. Using this formula and $\Omega_{19}=8.45$ which is listed in table A11 we get: 


$$
\Omega=G(y(H=1))=8.45-\left[(1.18-1) 3.93+\frac{1}{2} \frac{(1.18-1)^{2}}{\left(\frac{(1.18-0.83)}{(4.40-3.93)}\right)}\right]=7.72
$$

Thus, in 2009, the top 1 per cent held $7.72 \%$ of the income (total income minus imputation credits and net capital gains). (Note that due to the use of rounded numbers, the top 1 per cent share calculated in this example (7.72\%) is slightly different from the top 1 per cent share calculated using more precise numbers (7.77\% in Table A4)).

\section{Estimation of accrued capital gains using the HILDA Survey data}

Owner-occupied housing. Our estimate of accrued capital gains on the family home is based on estimates of home values provided by respondents in each wave of the survey. Thus, if the respondent did not change houses within the last two years, the estimated capital gain over the intervening year is simply equal to the change in the reported home value. For a household that sells the home between one wave and the next, the capital gain in that year is approximated by the ABS house price index over the last year for the capital city of the state of residence (House Price Indexes: Eight Capital Cities, Catalogue No. 6046.0—see Table A12) (ABS, 2013b), i.e.,

$$
c g_{o h, t}=p_{t} v_{o h, t-1}
$$

Where: $p_{t}$ is the percentage change (divided by 100) in the relevant house price index over year $t$ and $v_{o h, t-1}$ is the value of other housing owned by the household in the previous year, as reported by the respondent.

Other assets. Our estimates of accrued capital gains on non-owner-occupied housing, unincorporated businesses, equities and superannuation funds are based on asset holdings in 2006 and 2010, when detailed household wealth data was collected in the HILDA Survey. Our estimates of accrued capital gains on non-owner-occupied housing are approximated by the ABS house price index for the capital 
city of the state of residence, while unincorporated businesses and equity and superannuation fund holdings are assumed to track the Australian Stock Exchange ASX200 share price index (see Table A12), i.e.,

$$
\mathrm{cg}_{\mathrm{i}, \mathrm{t}}=\mathrm{p}_{\mathrm{t}} \mathrm{v}_{\mathrm{i}, \mathrm{t}-1}
$$

Where: $p_{t}$ is the percentage change (divided by 100) in the relevant (house or share) price index over year $t$ and $v_{i, t-1}$ is the estimated value of holdings of asset class $i$ in the previous year. For 2006-07, $v_{i, t-1}\left(=v_{i, 2006}\right)$ is equal to the actual value reported by the respondent in 2006, while for 2009-10 it is equal to:

$$
v_{i, 2009}=\frac{v_{i, 2010}}{\left(1+p_{2010}\right)}
$$

Where: $v_{i, 2010}$ is equal to the actual value reported by the respondent in 2010 .

Thus, the accrued capital gain on a non-home asset in 2006-07 is based on the (initial) reported value of the asset in 2006 and the change in the relevant price index between 1 July 2006 and 30 June 2007. By contrast, the accrued capital gain in 2009-10 is based on the (final) reported value of the asset in 2010 and the change in the relevant price index between 1 July 2009 and 30 June 2010.

Note that actual capital gains in the intervals between 2006 and 2007 and between 2009 and 2010 may diverge from estimated capital gains because of heterogeneity in rates of return, and also because asset holdings may change over the interval: we will not capture capital gains on assets acquired between 2006 and 2007 and assets disposed of between 2009 and 2010; and we will incorrectly attribute (some) capital gains to assets disposed of between 2006 and 2007 and assets acquired between 2009 and 2010 . 
Positive components:

1. Gross mixed income

2. Compensation of employees

3. Property income receivable: Interest

4. Property income receivable: Dividends

5. Secondary income receivable: Social benefits receivable: Workers' compensation

6. Secondary income receivable: Social benefits receivable: Social assistance benefits

Negative components:

7. Property income payable: Interest payable: Unincorporated enterprises

8. Household sector consumption of fixed capital
ABS description (if available)

The surplus or deficit accruing from production by unincorporated enterprises. It includes elements of both compensation of employees (returns on labour inputs) and operating surplus (returns on capital inputs).

The total remuneration, in cash or in kind, payable by an enterprise to an employee in return for work done by the employee during the accounting period. It is further classified into two sub-components: wages and salaries; and employers' social contributions. Compensation of employees is not payable in respect of unpaid work undertaken voluntarily, including the work done by members of a household within an unincorporated enterprise owned by the same household. Compensation of employees excludes any taxes payable by the employer on the wage and salary bill (e.g. payroll tax).

Includes current transfers to persons from general government in return for which no services are rendered or goods supplied. Principal components include: scholarships; maternity, sickness and unemployment benefits; family allowances; and widows', age, invalid and repatriation pensions.

The reduction in the value of fixed assets used in production during the accounting period resulting from physical deterioration, normal obsolescence or normal accidental damage. Unforeseen obsolescence, major catastrophes and the depletion of natural resources are not taken into account.

Note: The control total for income is the sum of the positive components minus the sum of the negative components. 
Table A9: Taxation Statistics-Details on sources and data items used

\begin{tabular}{|c|c|c|c|c|c|c|c|}
\hline Year & Tax tables $^{1}$ & $\begin{array}{l}\text { Tabulation by... } \\
\text { (number of brackets) }\end{array}$ & Income measure & $\begin{array}{l}\text { Taxable realized capital } \\
\text { gains }\end{array}$ & Dividends & Primary imputation credits & Subsidiary imputation credits \\
\hline $\begin{array}{l}1970-71 \text { and } \\
1971-72\end{array}$ & $1.5,1.15$ & Net income (38) & Net income & $\begin{array}{l}\text { Profit (or loss) from sale of } \\
\text { real estate, shares, etc. }\end{array}$ & [not separately tabulated] & N/A & N/A \\
\hline $\begin{array}{l}1972-73 \text { to } \\
1973-74\end{array}$ & $1.3,1.14(\mathrm{a})$ & Net income (35) & Net income & $\begin{array}{l}\text { Profit (or loss) from sale of } \\
\text { real estate, shares, etc. }\end{array}$ & [not separately tabulated] & N/A & N/A \\
\hline $1974-75$ & $\begin{array}{l}1.13 \\
1.14(\mathrm{a})\end{array}$ & Net income (28) & Net income & $\begin{array}{l}\text { Profit (or loss) from sale of } \\
\text { real estate, shares, etc. }\end{array}$ & [not separately tabulated] & N/A & N/A \\
\hline $1975-76$ & $1.3,1.14(\mathrm{c})$ & Net income (26) & Net income & $\begin{array}{l}\text { Profit (or loss) from sale of } \\
\text { real estate, shares, etc.' }\end{array}$ & [not separately tabulated] & N/A & N/A \\
\hline $1976-77$ & $1.4,1.7(\mathrm{a})$ & Net income (29) & Net income & $\begin{array}{l}\text { Profit (or loss) from sale of } \\
\text { real estate, shares, etc. }\end{array}$ & [not separately tabulated] & N/A & N/A \\
\hline $1977-78$ & $1.1,1.5(a)$ & Taxable income (29) & Net income & $\begin{array}{l}\text { Profit (or loss) from sale of } \\
\text { real estate, shares, etc.' }\end{array}$ & [not separately tabulated] & N/A & N/A \\
\hline $1978-79$ & $\begin{array}{l}1.12 \\
1.16(\mathrm{a})\end{array}$ & Taxable income (24) & Net income & $\begin{array}{l}\text { Profit (or loss) from sale of } \\
\text { real estate, shares, etc. }\end{array}$ & [not separately tabulated] & N/A & N/A \\
\hline $\begin{array}{l}1979-80 \text { to } \\
1981-82\end{array}$ & 1.4 & Taxable income (27) & Net income & $\begin{array}{l}\text { Profit (or loss) from sale of } \\
\text { real estate, shares, etc. }\end{array}$ & Interest and dividends ${ }^{2}$ & N/A & N/A \\
\hline $\begin{array}{l}1982-83 \text { to } \\
1984-85\end{array}$ & 1.5 & Taxable income (27) & Net income & $\begin{array}{l}\text { Profit (or loss) from sale of } \\
\text { real estate, shares, etc. }\end{array}$ & Net dividends ${ }^{3}$ & N/A & N/A \\
\hline $1985-86$ & $1.5,1.24$ & Taxable income (32) & Net income & Sale of property & $\begin{array}{l}\text { Gross dividends / Dividend } \\
\text { income }^{4}\end{array}$ & N/A & N/A \\
\hline 1986-87 & $1.5,1.24$ & Taxable income (32) & Net income & $\begin{array}{l}\text { Sale of property }+ \\
\text { Net capital gains }\end{array}$ & $\begin{array}{l}\text { Gross dividends / Dividend } \\
\text { income }^{4}\end{array}$ & N/A & N/A \\
\hline $1987-88$ & $1.5,1.24$ & Taxable income (31) & Net income' & $\begin{array}{l}\text { Sale of property + } \\
\text { Net capital gains }\end{array}$ & $\begin{array}{l}\text { Gross dividends - Total / } \\
\text { Dividend income }\end{array}$ & Imputation credit & Imputation credit \\
\hline 1988-89 & $1.5,1.24$ & Taxable income (31) & Net income' & Net capital gains & $\begin{array}{l}\text { Gross dividends - Total / } \\
\text { Dividend income - Total }\end{array}$ & Imputation credit primary & $\begin{array}{l}\text { Imputation credit total less } \\
\text { Imputation credit primary }\end{array}$ \\
\hline $1989-90$ & 1.5 & Taxable income (26) & Net income' & Net capital gains & Gross dividends - Total ${ }^{4}$ & Imputation credit primary & $\begin{array}{l}\text { Imputation credit total less } \\
\text { Imputation credit primary }\end{array}$ \\
\hline $\begin{array}{l}1990-91 \text { and } \\
1991-92\end{array}$ & 1.5 & Taxable income (26) & Net income' & Net capital gains & Gross dividends - Total ${ }^{4}$ & Primary imputation credit & $\begin{array}{l}\text { Total imputation credit less } \\
\text { Primary imputation credit }\end{array}$ \\
\hline 1992-93 & 1.5 & Taxable income (26) & Total income' & Net capital gains & Gross dividends - Total ${ }^{4}$ & Primary imputation credit & $\begin{array}{l}\text { Total imputation credit less } \\
\text { Primary imputation credit }\end{array}$ \\
\hline \multicolumn{2}{|l|}{ 1993-94 } & \multicolumn{6}{|c|}{ Taxation tables not used because of the limited number of income brackets. Top income shares are the average of the 1992-93 and 1994-95 shares. } \\
\hline 1994-95 & P18 & Taxable income (10) & Total income & Net capital gains & $\begin{array}{l}\text { Gross dividends received - } \\
\text { Total }^{4}\end{array}$ & Primary imputation credits & $\begin{array}{l}\text { Total imputation credits less } \\
\text { Primary imputation credits }\end{array}$ \\
\hline 1995-96 & I8 & Taxable income (10) & Total income & Net capital gains & $\begin{array}{l}\text { Gross dividends received - } \\
\text { Total }^{4}\end{array}$ & Primary imputation credits & $\begin{array}{l}\text { Total imputation credits less } \\
\text { Primary imputation credits }\end{array}$ \\
\hline 1996-97 & I11 & Taxable income (16) & Total income & Net capital gains & $\begin{array}{l}\text { Gross dividends received - } \\
\text { Total }^{4}\end{array}$ & Primary imputation credits & $\begin{array}{l}\text { Total imputation credits less } \\
\text { Primary imputation credits }\end{array}$ \\
\hline
\end{tabular}


Table A9 continued: Taxation Statistics—Details on sources and data items used

\begin{tabular}{|c|c|c|c|c|c|c|c|}
\hline Year & Tax tables ${ }^{1}$ & $\begin{array}{l}\text { Tabulation by... } \\
\text { (number of brackets) }\end{array}$ & Income measure & $\begin{array}{l}\text { Taxable realized capital } \\
\text { gains }\end{array}$ & Dividends & Primary imputation credits & Subsidiary imputation credits \\
\hline $1997-98$ & $\mathrm{I} 10$ & Taxable income (16) & Total income & Net capital gains & Dividends - Total ${ }^{4}$ & Imputation credit primary & $\begin{array}{l}\text { Imputation credit total less } \\
\text { Imputation credit primary }\end{array}$ \\
\hline 1998-99 & I8 & Taxable income (16) & Total income & Net capital gains & Dividends - Total ${ }^{4}$ & Primary imputation credits & $\begin{array}{l}\text { Total imputation credits less } \\
\text { Primary imputation credits }\end{array}$ \\
\hline 1999-00 & $5 B, 5 C$ & Taxable income (16) & Total income & Net capital gains & Total gross dividends ${ }^{4}$ & Primary imputation credit & $\begin{array}{l}\text { Total imputation credit less } \\
\text { Primary imputation credit }\end{array}$ \\
\hline $2000-01$ & $5 B, 5 D$ & Taxable income (16) & $\begin{array}{l}\text { Total income or } \\
\text { loss }\end{array}$ & Net capital gain & Total dividends ${ }^{4}$ & Imputation credit primary & $\begin{array}{l}\text { Total imputation credit less } \\
\text { Imputation credit primary }\end{array}$ \\
\hline $\begin{array}{l}2001-02 \text { to } \\
2003-04\end{array}$ & $5 B, 5 D$ & Taxable income (16) & $\begin{array}{l}\text { Total income or } \\
\text { loss }\end{array}$ & Net capital gain & Total dividends ${ }^{4}$ & Imputation credit primary & $\begin{array}{l}\text { Total imputation credit } \\
\text { (Franking tax offset) less } \\
\text { Imputation credit primary }\end{array}$ \\
\hline 2004-05 & $5 B, 5 D$ & Taxable income (16) & $\begin{array}{l}\text { Total income or } \\
\text { loss }\end{array}$ & Net capital gain & Total dividends $\mathrm{s}^{3,4}$ & Franking credit & $\begin{array}{l}\text { Total franking credit less } \\
\text { Franking credit }\end{array}$ \\
\hline 2005-06 & $5 B$ & Taxable income (22) & $\begin{array}{l}\text { Total income or } \\
\text { loss }\end{array}$ & Net capital gain & Total dividends ${ }^{4}$ & Franking credit & $\begin{array}{l}\text { Share of franking credit from } \\
\text { franked dividends }\end{array}$ \\
\hline $\begin{array}{l}2006-07 \text { to } \\
2009-10\end{array}$ & $5 B, 5 \mathrm{D}$ & Taxable income (22) & $\begin{array}{l}\text { Total income or } \\
\text { loss }\end{array}$ & Net capital gain & Total dividends ${ }^{4}$ & Franking credit & $\begin{array}{l}\text { Total franking credit less } \\
\text { Franking credit }\end{array}$ \\
\hline $2010-11$ & 10 & Taxable income (22) & $\begin{array}{l}\text { Total income or } \\
\text { loss }\end{array}$ & Net capital gain & $\begin{array}{l}\text { Dividends unfranked } \\
\text { amount + Dividends } \\
\text { franked amount }^{5}\end{array}$ & Dividends franking credit & $\begin{array}{l}\text { Share of franking credit from } \\
\text { franked dividends }\end{array}$ \\
\hline
\end{tabular}

Notes: ${ }^{1}$ Tax table numbers are as they appear in the Australian Taxation Office publication Taxation Statistics for the relevant tax year (Commissioner of Taxation, 1971 to 2009 ). ${ }^{2}$

From 1979 to 1981, dividends are combined with interest. For these three years, we impute dividends by assuming the 1982 ratio of dividends to interest in 1982 applies. ${ }^{3}$ Net dividends are equal to gross dividend income less deductions for expenses incurred in gaining that income. ${ }^{4}$ From 1985 to 2009 , the tax tables contain total dividends, which include both franked and unfranked dividends. ${ }^{5}$ In 2010, the income category 'Total dividends' is missing from the tax table and is therefore calculated as the sum of unfranked and franked dividends. 
Table A10: Top 1 per cent income shares based on unit record tax data (one per cent sample file)

\begin{tabular}{|c|c|c|c|c|c|c|c|}
\hline & 2003 & 2004 & 2005 & 2006 & 2007 & 2008 & 2009 \\
\hline $\begin{array}{l}\text { (1) Including both imputation credits \& capital } \\
\text { gains - 'Replicated' }\end{array}$ & 8.40 & 8.42 & 8.82 & 9.98 & 8.01 & 7.22 & 7.51 \\
\hline \multicolumn{8}{|l|}{ Removing imputation credits only } \\
\hline (2) 'Replicated' & 7.97 & 7.97 & 8.29 & 9.28 & 7.59 & 6.83 & 7.20 \\
\hline (3) 'Correct' & 7.95 & 7.96 & 8.32 & 9.25 & 7.59 & 6.90 & 7.26 \\
\hline \multicolumn{8}{|l|}{ Removing capital gains only } \\
\hline (4) 'Replicated' & 7.72 & 7.58 & 7.85 & 8.24 & 6.70 & 6.71 & 7.12 \\
\hline (5) 'Correct' & 7.91 & 7.75 & 8.05 & 8.45 & 6.91 & 6.81 & 7.23 \\
\hline \multicolumn{8}{|l|}{ Removing both imputation credits and capital gains } \\
\hline (6) 'Replicated’ & 7.29 & 7.12 & 7.30 & 7.51 & 6.26 & 6.30 & 6.78 \\
\hline (7) 'Correct' & 7.46 & 7.29 & 7.54 & 7.77 & 6.49 & 6.46 & 6.97 \\
\hline $\begin{array}{l}\text { Error with imputation credits and capital gains } \\
\text { removed }[(6)-(7)] \\
\text { Error with imputation credits and capital gains }\end{array}$ & -0.17 & -0.17 & -0.24 & -0.26 & -0.23 & -0.16 & -0.19 \\
\hline not removed $[(1)-(7)]$ & 0.94 & 1.13 & 1.28 & 2.21 & 1.52 & 0.76 & 0.54 \\
\hline
\end{tabular}

Notes: All estimates are income shares of the top 1 per cent calculated from tax tables constructed to match those used in the analysis reported in the main body of this paper. 'Replicated' estimates assume no re-ranking of individuals across income brackets. 'Correct' estimates do not impose the assumption of no re-ranking of individuals. 
Table A11: Taxation table from the 2009 Australian Taxation Statistics

\begin{tabular}{|c|c|c|c|c|c|c|c|c|c|c|c|c|}
\hline \multirow{3}{*}{$\begin{array}{l}\text { Range } \\
\text { No. }(i) \\
1\end{array}$} & \multicolumn{7}{|c|}{ From Table 5B } & \multicolumn{5}{|c|}{ Calculations } \\
\hline & \multicolumn{2}{|c|}{$\begin{array}{c}\text { Bounds of taxable } \\
\text { income }(\$)\end{array}$} & \multirow{2}{*}{$\begin{array}{c}\begin{array}{c}\text { No. of } \\
\text { persons }\end{array} \\
17,795\end{array}$} & \multirow{2}{*}{$\begin{array}{c}\text { Total income } \\
(\$)\end{array}$} & \multirow{2}{*}{$\begin{array}{c}\begin{array}{c}\text { Imputation credits } \\
\text { (IC) }(\$)\end{array} \\
1,221,789\end{array}$} & \multirow{2}{*}{$\begin{array}{c}\begin{array}{c}\text { Capital gains } \\
(\mathrm{CG})(\$)\end{array} \\
4,088,788\end{array}$} & \multirow{2}{*}{$\begin{array}{c}\begin{array}{c}\text { Total income minus } \\
\text { IC and CG (\$) }\end{array} \\
55,787,038\end{array}$} & \multirow{2}{*}{$\begin{array}{c}\begin{array}{c}\text { Mean } \\
(\$)\end{array} \\
3,135\end{array}$} & \multirow{2}{*}{$\begin{array}{c}\begin{array}{c}\% \text { of } \\
\text { persons }\end{array} \\
0.10\end{array}$} & \multirow{2}{*}{$\begin{array}{c}\begin{array}{c}\text { Cumul. } \\
\left(H_{i}\right)\end{array} \\
51.22\end{array}$} & \multirow{2}{*}{$\begin{array}{c}\begin{array}{c}\% \text { of } \\
\text { income }\end{array} \\
0.01\end{array}$} & \multirow{2}{*}{$\begin{array}{c}\begin{array}{c}\text { Cumul. } \\
\left(\Omega_{i}\right)\end{array} \\
67.88\end{array}$} \\
\hline & 0 & 6,000 & & & & & & & & & & \\
\hline 2 & 6,001 & 10,000 & 7,665 & $66,945,059$ & 974,349 & $3,089,157$ & $62,881,553$ & 8,204 & 0.04 & 51.12 & 0.01 & 67.88 \\
\hline 3 & 10,001 & 15,000 & 13,150 & $183,655,299$ & $1,013,278$ & $4,204,980$ & $178,437,041$ & 13,569 & 0.07 & 51.07 & 0.02 & 67.87 \\
\hline 4 & 15,001 & 20,000 & 576,390 & $11,002,730,828$ & $72,426,942$ & $113,404,343$ & $10,816,899,543$ & 18,767 & 3.24 & 51.00 & 1.33 & 67.85 \\
\hline 5 & 20,001 & 25,000 & 656,230 & $15,805,137,943$ & $90,671,037$ & $134,986,430$ & $15,579,480,476$ & 23,741 & 3.69 & 47.76 & 1.91 & 66.52 \\
\hline 6 & 25,001 & 30,000 & 699,455 & $20,546,554,114$ & $146,558,410$ & $182,258,402$ & $20,217,737,302$ & 28,905 & 3.93 & 44.07 & 2.48 & 64.61 \\
\hline 7 & 30,001 & 35,000 & 833,820 & 28,793,007,349 & $259,679,492$ & $246,747,701$ & $28,286,580,156$ & 33,924 & 4.69 & 40.13 & 3.47 & 62.13 \\
\hline 8 & 35,001 & 40,000 & 820,470 & $32,423,527,762$ & $238,639,584$ & $239,165,613$ & $31,945,722,565$ & 38,936 & 4.61 & 35.44 & 3.92 & 58.66 \\
\hline 9 & 40,001 & 45,000 & 736,050 & $32,859,871,530$ & $190,005,560$ & $217,267,121$ & $32,452,598,849$ & 44,090 & 4.14 & 30.83 & 3.98 & 54.73 \\
\hline 10 & 45,001 & 50,000 & 650,770 & $32,445,111,067$ & $183,392,627$ & $216,604,804$ & $32,045,113,636$ & 49,242 & 3.66 & 26.69 & 3.93 & 50.75 \\
\hline 11 & 50,001 & 55,000 & 570,435 & $31,435,710,422$ & $181,837,336$ & $211,448,426$ & $31,042,424,660$ & 54,419 & 3.21 & 23.03 & 3.81 & 46.82 \\
\hline 12 & 55,001 & 60,000 & 499,605 & $30,136,847,659$ & $174,605,996$ & $216,587,194$ & $29,745,654,469$ & 59,538 & 2.81 & 19.82 & 3.65 & 43.01 \\
\hline 13 & 60,001 & 70,000 & 799,660 & $54,350,202,194$ & $354,762,621$ & $432,757,342$ & $53,562,682,231$ & 66,982 & 4.50 & 17.01 & 6.57 & 39.36 \\
\hline 14 & 70,001 & 80,000 & 647,450 & $51,013,235,351$ & $696,941,971$ & $526,493,917$ & 49,789,799,463 & 76,901 & 3.64 & 12.51 & 6.11 & 32.79 \\
\hline 15 & 80,001 & 90,000 & 418,680 & $37,104,957,983$ & $454,500,436$ & $449,363,809$ & $36,201,093,738$ & 86,465 & 2.35 & 8.87 & 4.44 & 26.68 \\
\hline 16 & 90,001 & 100,000 & 270,060 & $26,752,071,476$ & $303,036,133$ & $373,618,005$ & $26,075,417,338$ & 96,554 & 1.52 & 6.52 & 3.20 & 22.23 \\
\hline 17 & 100,001 & 150,000 & 558,370 & 69,521,930,098 & $1,224,928,852$ & $1,415,005,595$ & $66,881,995,651$ & 119,781 & 3.14 & 5.00 & 8.21 & 19.03 \\
\hline 18 & 150,001 & 180,000 & 120,500 & $20,749,623,483$ & $757,087,292$ & $639,466,915$ & $19,353,069,276$ & 160,606 & 0.68 & 1.86 & 2.37 & 10.83 \\
\hline 19 & 180,001 & 250,000 & 107,560 & 23,407,982,041 & $896,511,108$ & $834,625,467$ & $21,676,845,466$ & 201,533 & 0.60 & 1.18 & 2.66 & 8.45 \\
\hline 20 & 250,001 & 500,000 & 75,740 & $26,337,287,330$ & $1,281,063,912$ & $1,012,274,365$ & $24,043,949,053$ & 317,454 & 0.43 & 0.57 & 2.95 & 5.79 \\
\hline 21 & 500,001 & $1,000,000$ & 19,070 & 13,428,279,958 & $935,513,022$ & $674,415,590$ & $11,818,351,346$ & 619,735 & 0.11 & 0.15 & 1.45 & 2.84 \\
\hline 22 & $1,000,001$ & & 7,045 & $15,274,373,372$ & $1,734,799,703$ & 2,200,912,689 & $11,338,660,980$ & $1,609,462$ & 0.04 & 0.04 & 1.39 & 1.39 \\
\hline Total & & & $9,105,970$ & $573,700,139,933$ & $10,180,171,450$ & $10,348,786,653$ & $553,171,181,830$ & 60,748 & 51.22 & & 67.88 & \\
\hline Cont & income & $\$ 814,88$ & 00,000 & & & & & & & & & \\
\hline Contro & population & 17,7 & 266 & & & & & & & & & \\
\hline Mean & come $(\mu)$ & $\$ 45$ & & & & & & & & & & \\
\hline
\end{tabular}


Table A12: House price and share price indices used to estimate accrued capital gains-Percentage changes in each financial year

\begin{tabular}{lcc}
\hline & $2006-07$ & $2009-10$ \\
\hline House price indices & & 11.64 \\
New South Wales & 6.67 & 13.28 \\
Victoria & 17.41 & 3.61 \\
Queensland & 19.17 & 6.18 \\
Western Australia & 3.77 & 6.91 \\
South Australia & 17.54 & 5.75 \\
Tasmania & 9.36 & 8.91 \\
Northern Territory & 12.15 & 11.45 \\
Australian Capital Territory & 13.18 & -3.39 \\
Share price index (ASX200) & 27.44 & \\
Sources: ABS (2013b) House Price Indexes: Eight Capital Cities, Catalogue No. 6046.0; ASX200: Downloaded from \\
<http://www.abs.gov.au/AUSSTATS/abs@.nsf/DetailsPage/6416.0Dec\%202012?OpenDocument>
\end{tabular}

